
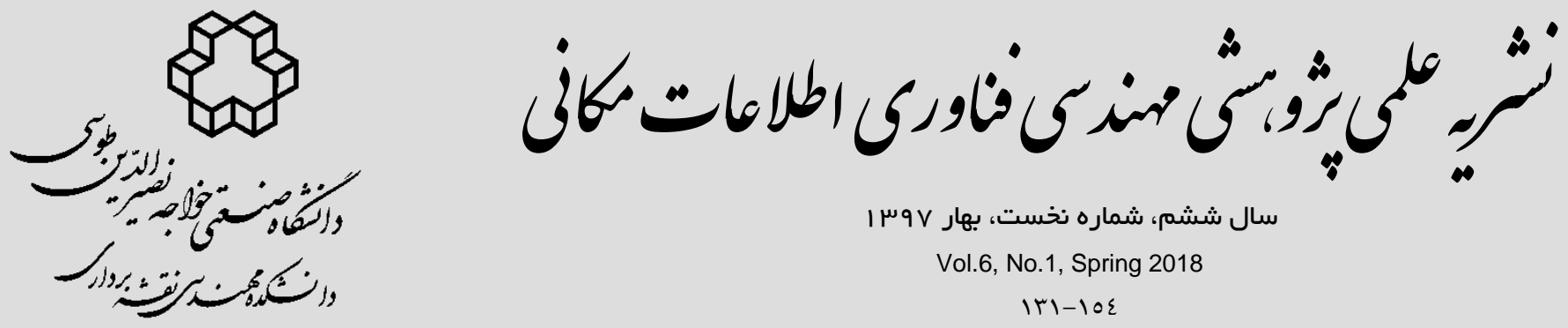

I س سال ششم،، شماره نخست، بهار

Vol.6, No.1, Spring 2018

$|r|-10 \varepsilon$

\author{
برنامهريزى جندهدفهى كاربرى اراضى شهرى و مدلسازى تغييرات آنها با استفاده از \\ الكوريتهم تكاملى جند هدفه بر مبناى تجزيه \\ زهره معصومى "', محمدسعدى مسعرى

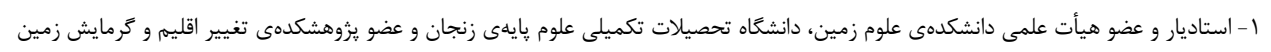

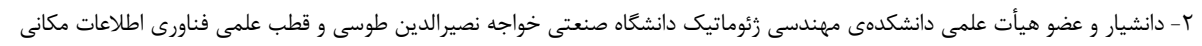

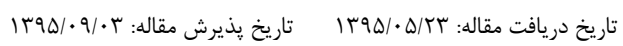

جكيده

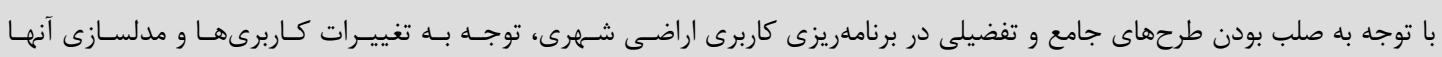

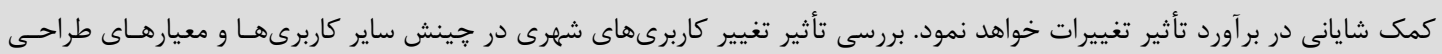

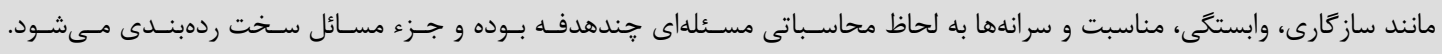

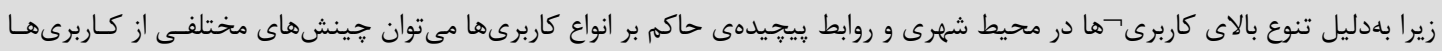

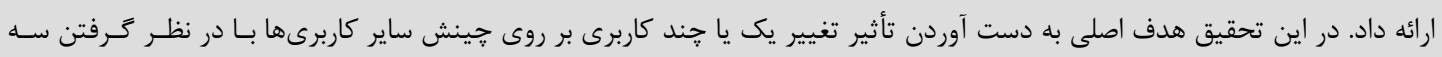

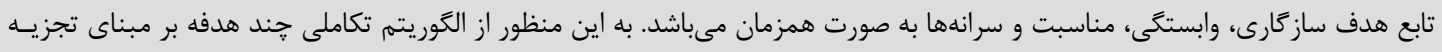
(MOEA/D Multi-Objective Evolutionary Algorithm based on Decomposition)

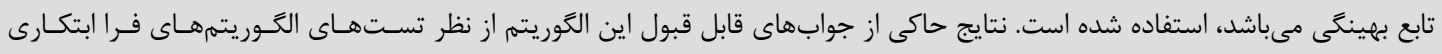

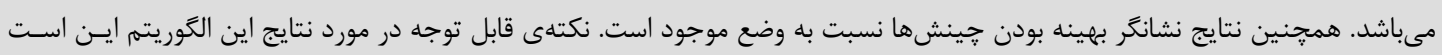

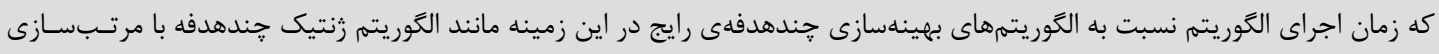

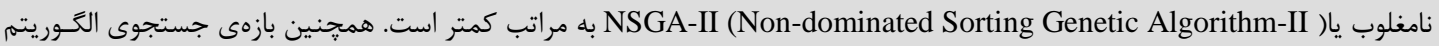
نيز بيش از الكوريتم NSGA-II مى نمباشد.

كليدوازهها: تغيير كاربرى اراضى شهرى، سيستم اطلاعات مكانى، MOEA/D، بهينهسازى جندهدفه، حمايت از تصميمَيرى 
شـكل محاسـباتى بـهـ ايـن مسـئله تـوجهى نمسى شــون

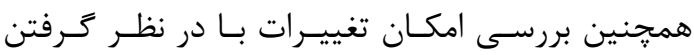

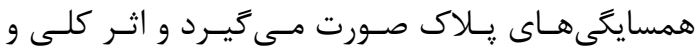
منطقهاى تغيير مورد بررسى واقع نمسىشـود. از طرفى نـى

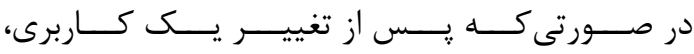
جينشهاى بهينهى مختلـف از كـاربرى هـاى موجـود و تأثير محاسباتى آن تغيير به مدير طورى ارائه شـود كـهـ

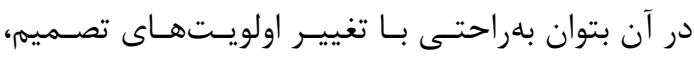
نتيجهى تغيير را مشاهده كرد، تصميم كيرى آسانتسر و و صحيحتر خواهد شد. در زمينهى مدلسازى تغييرات شهرى و به دست آوردن

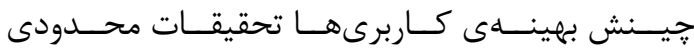

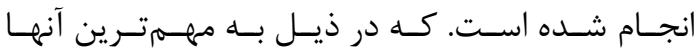
يرداخته خواهد شد. در برخى تحقيقات، هدف اصلى بهينـهسـازى همزمـان

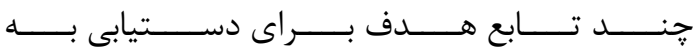
جينش بهينهى كاربرىها بوده اسـت. در ايسن دسـته از

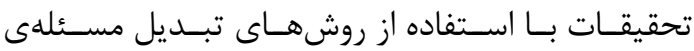

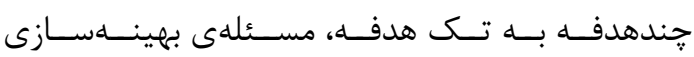

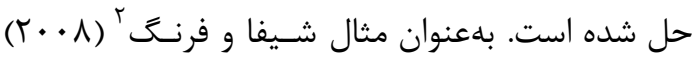
اقدام به تخصيص كاربرى در هر زمين با در نظر كرفتن

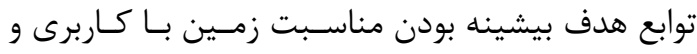

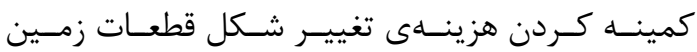
نموده است. روش بهينهسازى بهكار رفتـه بهينـهسـازى

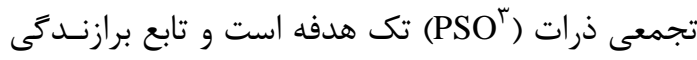

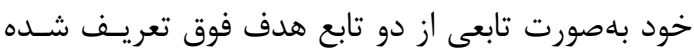

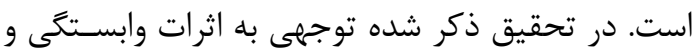

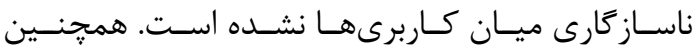

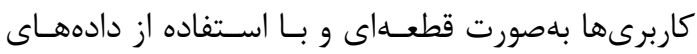
بردارى وارد مسئله شدهاند. بهعلاوه از آنجائيكـه مسـئله

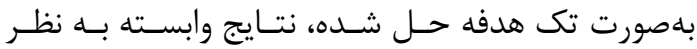

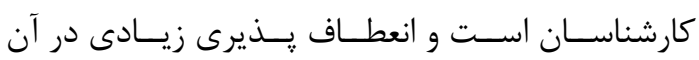

\footnotetext{
${ }^{2}$ Shiffa and Freng

${ }^{3}$ Particle Swarm Optimization
}

| - 1- (- مقدمه

ساختار شهرها و جينش كاربرى در آنها در پاسخكوئى

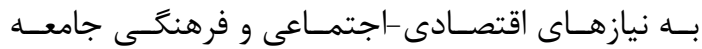
شكل مى گيرند و همراه با تغيير در اين نيازها، ناكزير از

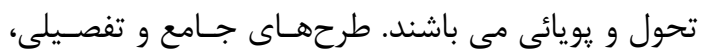
طرحهاى فيزيكى بلند مدتى مسىباشـند كـه در تهيـهـ و

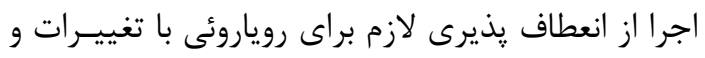

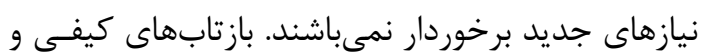

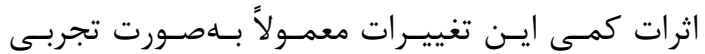
تعيين مىشود و با توجه به پِيجيده بودن مسئله، از نظر

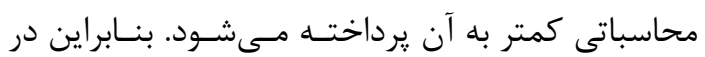
صورتيكه در طرحها و برنامههاى شهرى حالت ديناميك و يوياى شهر و تغييرات كاربرى در نظـر كرفتـه نشـود،

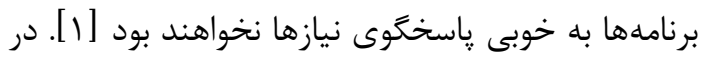
اين شرايط به منظور ايجاد تعادل و توازن در المانهـاى بـإن

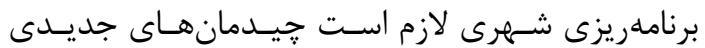

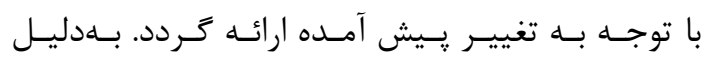

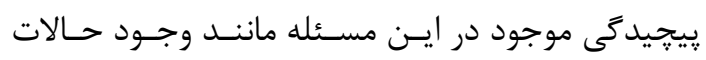
مختلف جينش، وجود المانهاى كمى و كيفى متنـوع

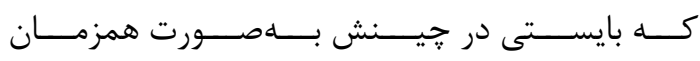

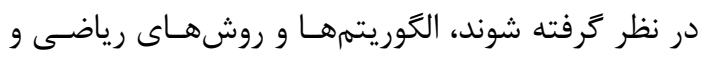

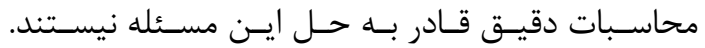
محاسبات تقريبى با استفاده از الكوريتمهاى بهينهسازى

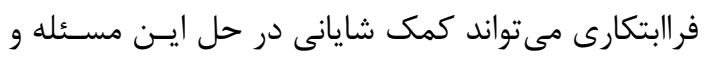

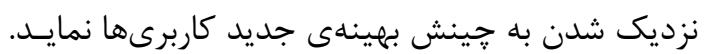
با نيل به ايـن هـدف طـرحهـاى تفصـيلى موجـود كـهـ

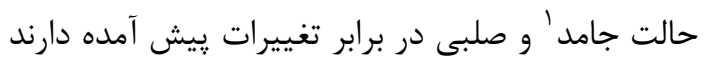

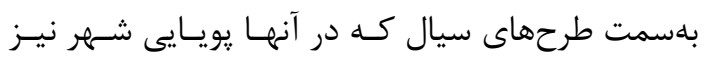
مد نظر قرار مى كيرد حركت خواهند كرد. در طرحهـاى

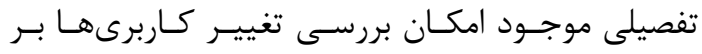

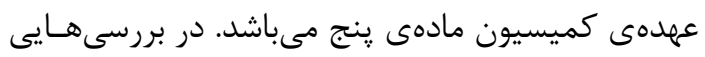

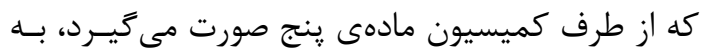

\section{${ }^{1}$ Rigid}


هدف به دست آوردن جينش بهينهى جهار نوع كاربرى

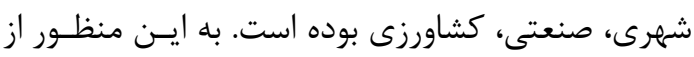

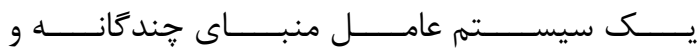

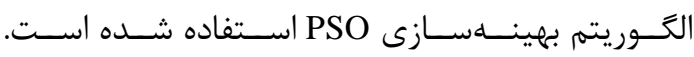

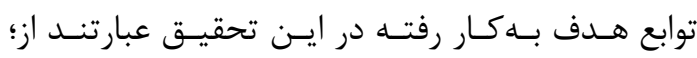
بيشينهسازى سود اقتصادى، اجتماعى و زيست-محيطى

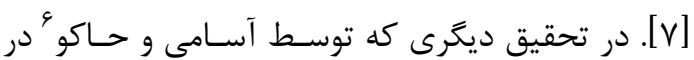

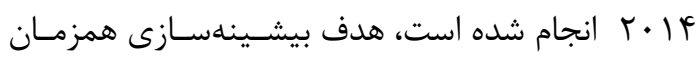

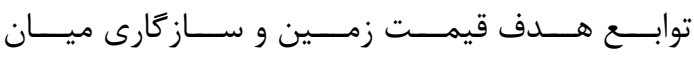

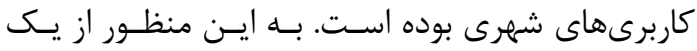

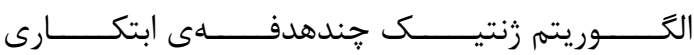

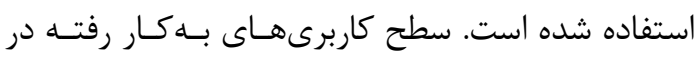

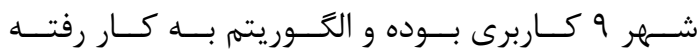

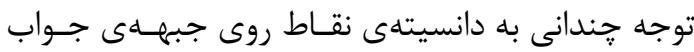

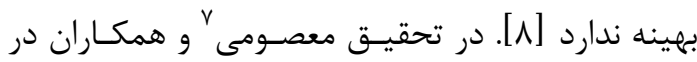

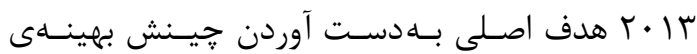
اراضى شهرى در يـك محـيط وكتـورى بـا اسـتفاده از

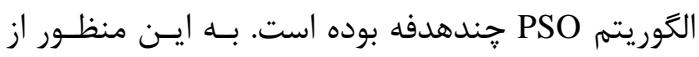

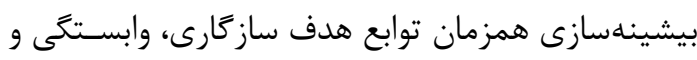

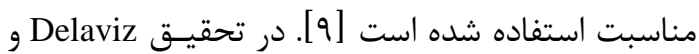

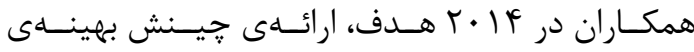
كاربرىهاى شهرى به منظور كـاهش آسـيبـيـذيرى در

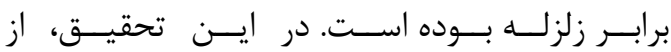

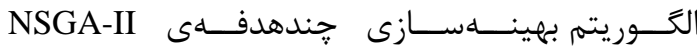

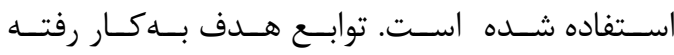
شـامل بيشـينهسـازى سـازعارى كاربريهـاى مجـاور، دسترسى كاربرىها، دسترسيذيرى كاربريهاى بهداشتى

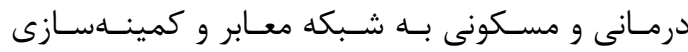

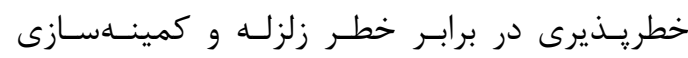

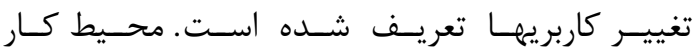
اين الكوريتهم رسـترى بـوده و كـاربرىهـاى شهرى در 1 دسته تقسيمبندى شدهاند [ [1].

\footnotetext{
${ }^{6}$ Asami and Haque
}

${ }^{7}$ Masoumi

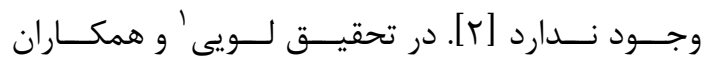

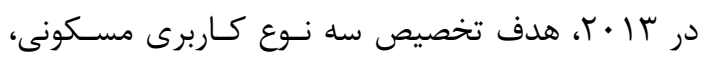

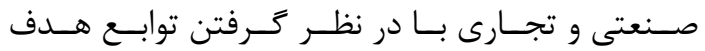

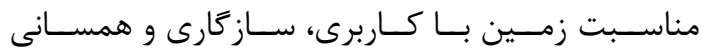

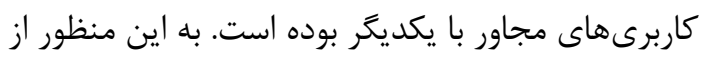
روش تلفيقـى بهينـهـســازى تجمعسى ذرات (r)

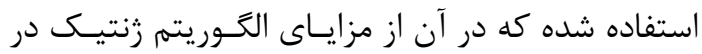
الكوريتم PSO بهره كرفته شده است. در تحقيق مذكور

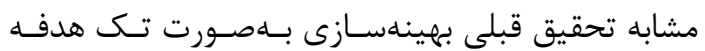

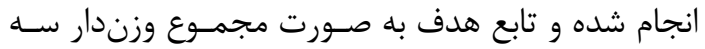

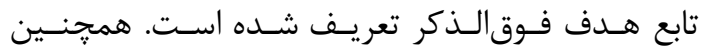

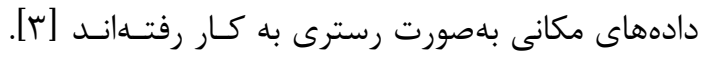
تحقيقات مشابهى نيز در [ع و ها]، بهمنظور بهينهسازى دادي

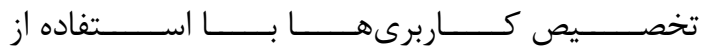
الكوريتمهاى بهينهسازى تك هدفه انجام شده است.

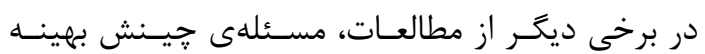

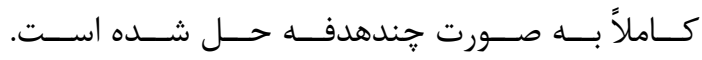
بلاعنوان مثال، در تحقيقى كه توسط كـائوّ و همكـاران

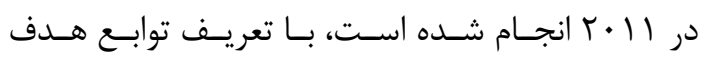

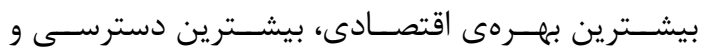

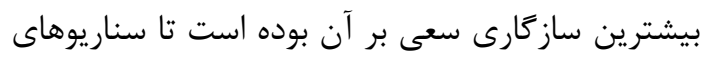

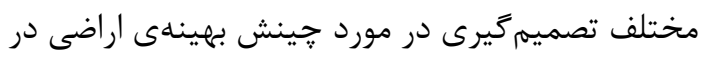
يك شهر جديد ارائه شود. در ايسن تحقيـق از الخــوريته

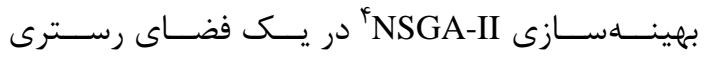

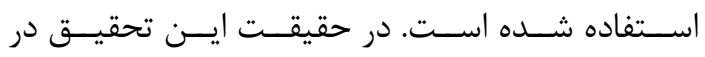

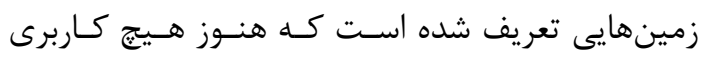

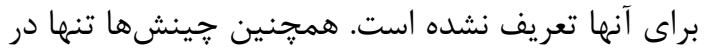

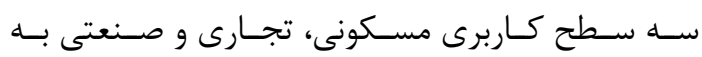

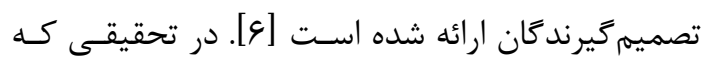

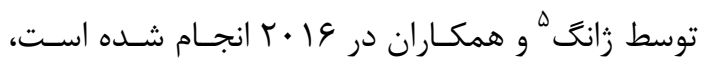

\footnotetext{
${ }^{1}$ Liu

${ }^{2}$ Hybrid Particle Swarm Optimization

${ }^{3} \mathrm{CaO}$

${ }^{4}$ Non-dominates Sorting Genetic Algorithm-II

${ }^{5}$ Zhang
} 


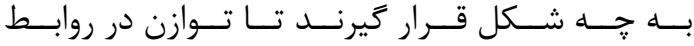

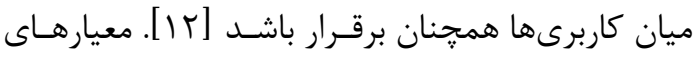
جينش بهينهى كاربرىهاى شهرى را در كنـار يكـديكر

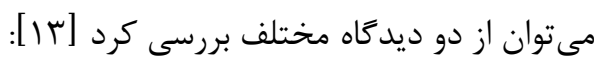

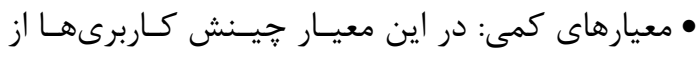

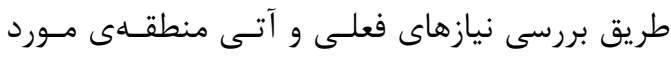
مطالعه در فضا در نظر كرفته مىشود.

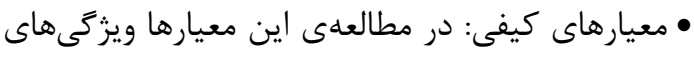
كيفى ذيل بررسى مى شوند: ○ وابستخى: كاهى اوقات فعاليت يك كاربرى، وابسـته

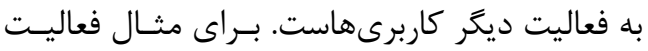

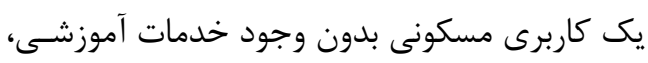
درمانى و تجارى در فواصلى از آن ناقص است.

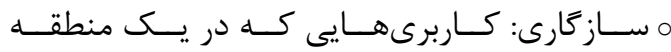

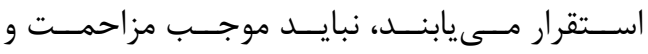
مانع اجراى فعاليتهاى ديخر شوند.

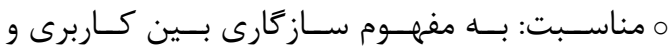
خصوصيات فيزيكى محل استقرار آن است.

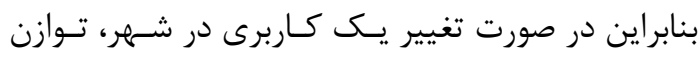
اجزا در معيارهاى كمى و كيفى بر هم خواهد خورد. در

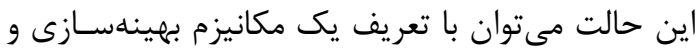

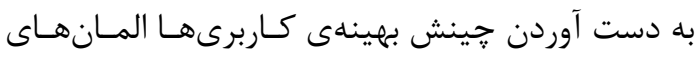

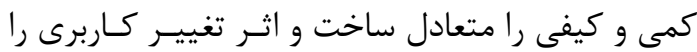
مدلسازى نمود. همانطور كه ملاحظه مىشود در صورت

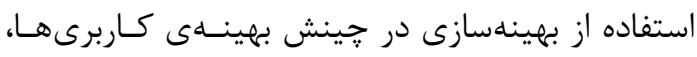

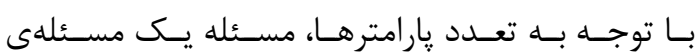
بهينهسازى קندهدفه خواهد بود. براى آشـنايى بيشـتر خوانندكان محترم در اين بخش به تئورى ايـن مسـئله يرداخته خواهد شد.

\section{r-Y T- بهينه سازى جندهدفه و روشهاى برخـــورد}

بهينهسازى קندهدفه، همجون بهينهسازى تـك هدفـه،

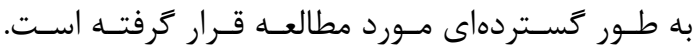
الكَوريتمها و مطالعات كاربردى زيـادى وجـود دارد كـهـ
ادامهى مقاله حاضر در جهار بخش تنظيم شـده اسـت.

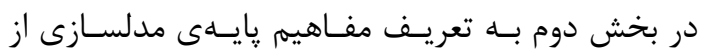
جمله بهينهسازى جندهدفه، روش كار الكوريتم تكاملى

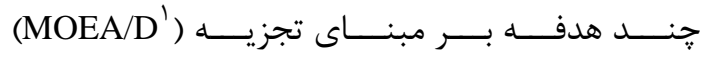

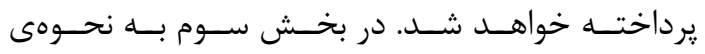

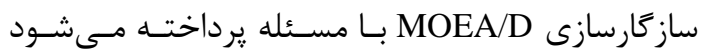

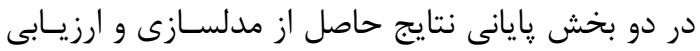
آنها ارائه مىشود.

\section{r- مبانى نظرى تحقيق}

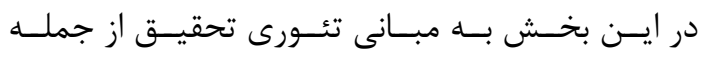

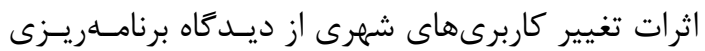

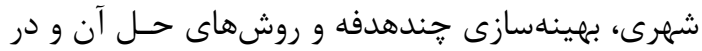
نهايت روش كار MOEA/D يرداخته خواهد شد.

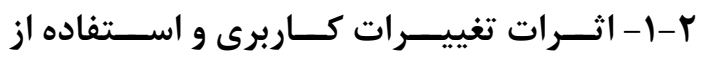
بهينهسازى جينش كاربرىها بهمنظور مديريت آن

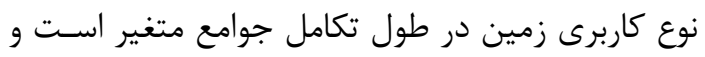

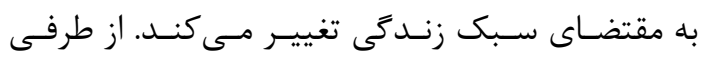

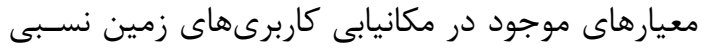

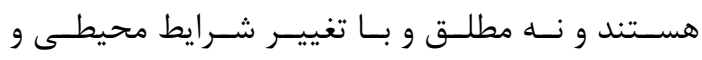

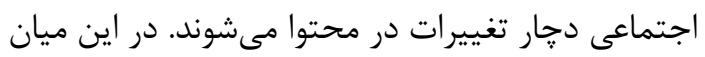

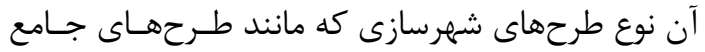

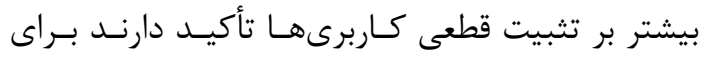

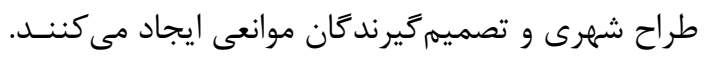

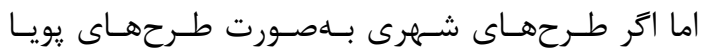

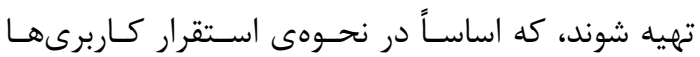

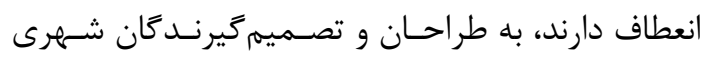
امكان بيشترى در تركيب فعاليت و فضا داده خواهد شد نداند

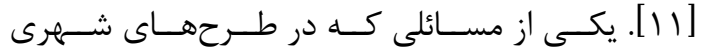
مطرح مىشود، اثر تغيير يك يا جند كاربرى بر نحسونى

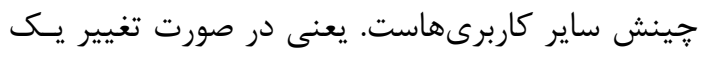
يا جند كاربرى با توجه به شرايط جديد، سـاير كـاربرى

${ }^{1}$ Multi-Objective Evolutionary Algorithm based on Decomposition 
شــروط موجــود اسـت. بــهـــــوان مثـــال در حالــت

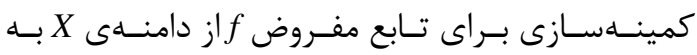
بــرد فضـاى اعـداد حقيقـى (R) مطــابق رابطـــهـ (1)

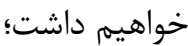
$\min _{x} f(x)$

$$
f: X \rightarrow R \quad \text { رابطه (1) }
$$

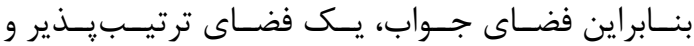

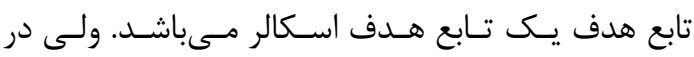

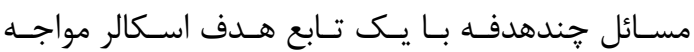
نيستيم بلكه خود تابع هدف يك بردار است يعنسى احـر رابطه (1) براى يك مسئلهى جندهدفـهـ تعريـف شـود، طبق رابطه (r) خواهيم داشت؛ بك (r) بكائ
شامل هدف هاى جند مانهاى هستند. در اغلب راهحلها

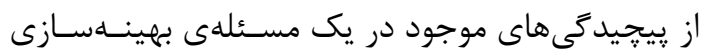

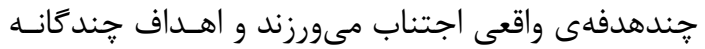

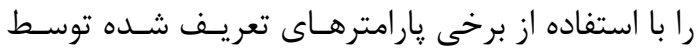

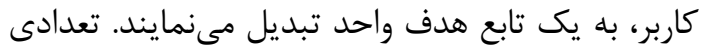
از مطالعات شامل مقايسهى طرحهـاى مختلـف جنـين تبديل هايى هستند و دلايلى جهت نشان دادن مطلـوب

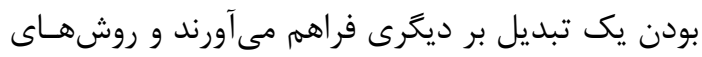

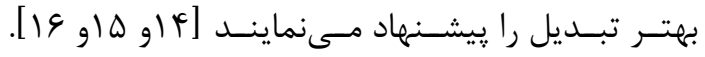

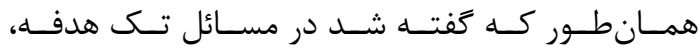

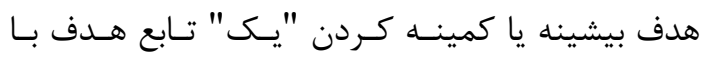

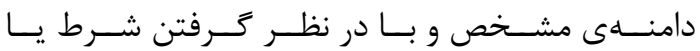

$\min _{x} f(x) \quad f: X \rightarrow R^{m} \quad, f=\left(f_{1}, f_{2}, \ldots, f_{m}\right)$

رابطه (r)

مقايسهاى مانند كوجكتر (>) يا بزرَتر (>) در اين فضا

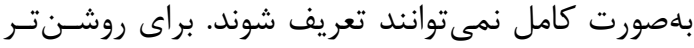

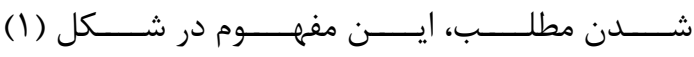
نمايش ، داده شده است.

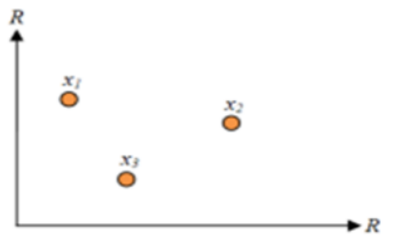

ب
يعنى تابع f خود m مولفـه دارد و يـك بـردار $m$ بعـدى

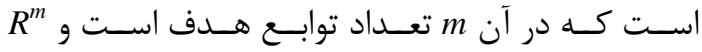

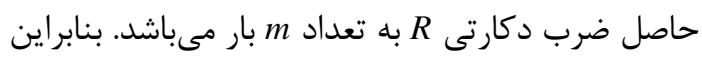

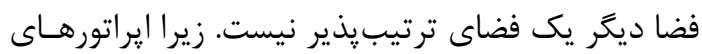

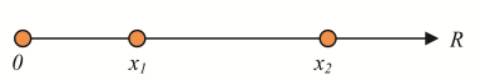

شكل ا: نمايش فضاى جواب تك بعدى و دو بعدى در R2 و R2 ( شكل ا-الف) فضاى ترتيب بذير تك بعدى و شكل ا-ب) فضاى دو بعدى توابع هدف)

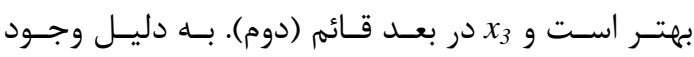

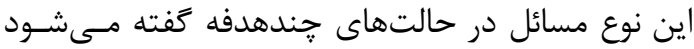

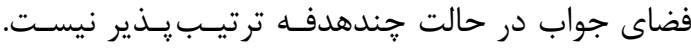

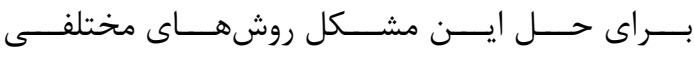

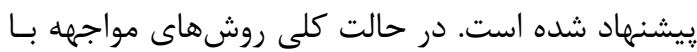

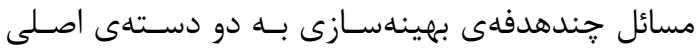

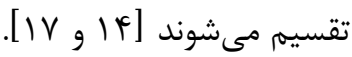
• تبديل مسئلهى جندهدفه به تك هدفه (تجزيـه): در اين روشها فضاى مسئله به يك فضاى اسكالر

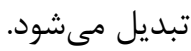

شكل (ا -الف) فضـاى R و دو نقطـهى نشان مى دهد. در اين فضا عملكَرهاى مقايسهاى بهدليل ترتيب يذير بودن فضا قابل تعريف هستند. همانطور كه

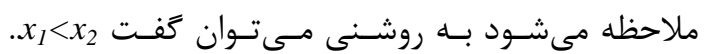

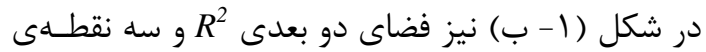


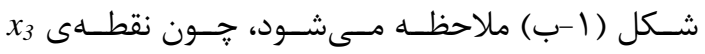
از نظر هر دو بعد بهتـر (كـوجكتر) از نقطـهـى

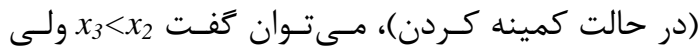

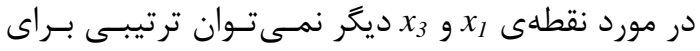

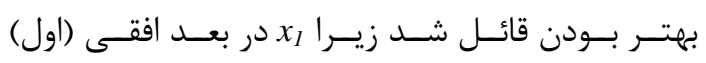


در مسئلهى حاضر به دليل حجم بالاى فضاى جسـتجو و گَسســته بــودن مســــله ' از الخَــوريتم استفاده شده است. ايسن الخَـوريتهم بــرخلاف بسـيارى از ماز الخوريتمهاى فرابتكارى ديخر، بر مبناى غلبدى جوابها در فضـاى جنــد بعـدى توابـع هـدف عمـل نمسى كنــد. بهايسن دليـل داراى سـرعت بـالايى در حــل مســائل بـا توابع هدف متنوع و حجم بالاى فضاى جستجو مىباشد

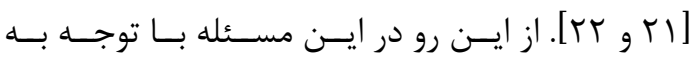

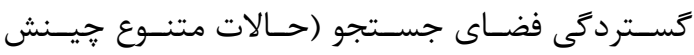
كاربرىها در كنار يكديگر) و بالا بودن تعداد توابع هدف (F تابع هدف كـهـ در ادامـه توضـيح داده خواهـد شـدـ

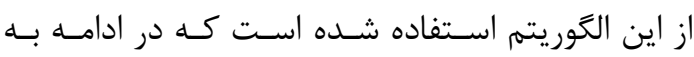
روش كار اين الكوريتم يرداخته خواهد شد.

\section{MOEA/D r-r}

اين الكَوريتم بر اساس تجزيـه مســـلهى جنـدهدفـهـ بـهـ

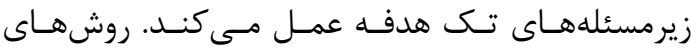

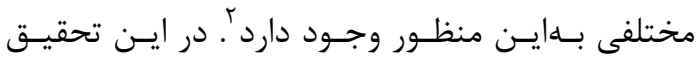

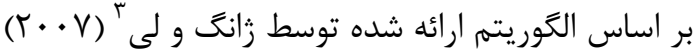

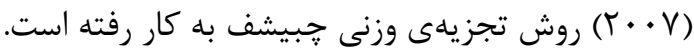
در اين روش با فرض

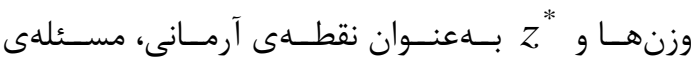
تخمين جبهلهى جواب را مسىتـوان بـهـ N زيرمســـلهى

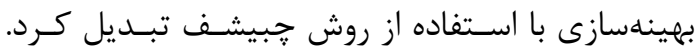

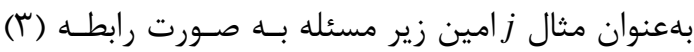
تعريف مىشود [rr]

$$
g^{t e}\left(x \mid \lambda^{j}, z^{*}\right)=\max \left\{\lambda_{i}{ }^{j}\left|f_{i}(x)-z_{i}^{*}\right|\right\} \quad \text { رابطه (广) }
$$

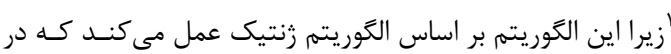
حل مسائل گسسته توانايى هاى لازم را داراست.

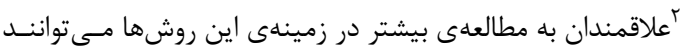
به (2007) Zhang and Li( رجوع كنند.

${ }^{3}$ Zhang and $\mathrm{Li}$
• حل مستقيه: در اين روشها معيارى براى برتـرى

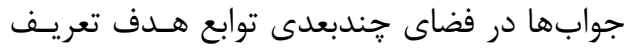

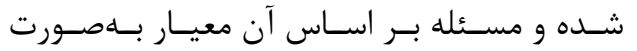

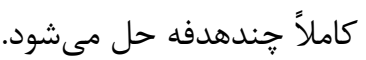

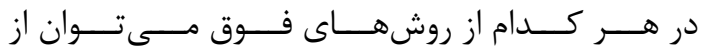
روشهاى رياضى و قطعى و يا الكوريتمهــاى ابتكـارى و فرا ابتكارى در حل مســله اسـتفاده نمـود. اسـتفاده از روشهاى رياضى در مسائل جندهدفه كه داراى فضـاى جســتجوى وســيعى هســـتند در بســـيارى از مــــارد مشكل است و حتى در برخى موارد امكان يذير نيسـت.

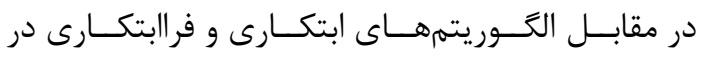

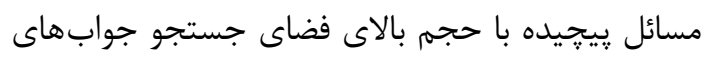

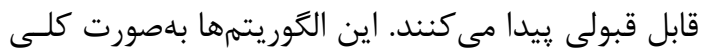
در فضـاى جسـتجو بــه دنبــال جــواب بهينــه هسـتـند در حالى كه به صورت محلى نيز بـه جــوابهـاى محلـى

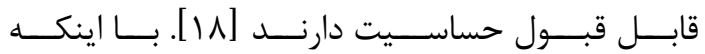
اين الكوريتمها در فضاى جسـتجو معمـولاً بـهـ بهينـهـى قطعى نمىرسند ولى حتى الامكان به آن نزديك شده و جوابهاى قابل قبولى توليد مىنمايند. الكوريتمهاى ابتكارى و فرابتـارى متتــوعى بــراى حــل

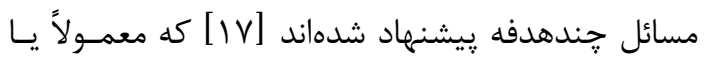

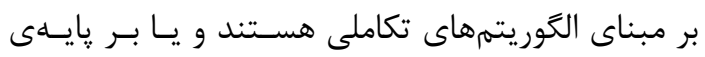

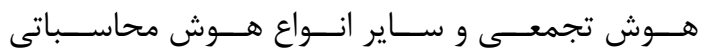

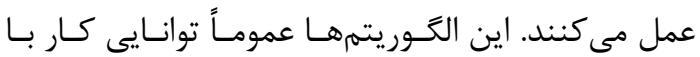
مجموعهاى از جوابهاى متفاوت بهعنوان جمعيت اوليه

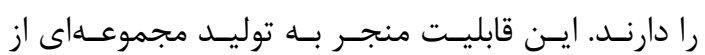

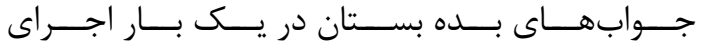

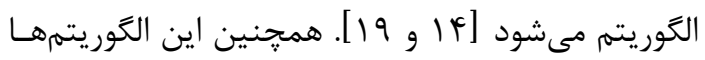

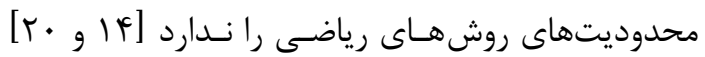
در فضاهاى جستجوى گسترده جوابهاى قابـل قبـولى

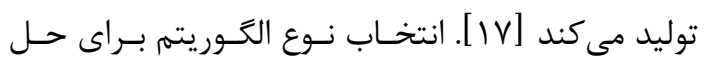

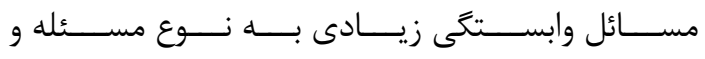
حجم فضاى جستجو دارد. 


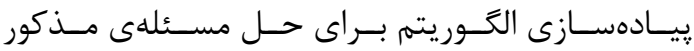

$$
\begin{aligned}
& \text { تشريح خواهد شد. }
\end{aligned}
$$

\section{|- (- - - منطقهى مطالعاتى}

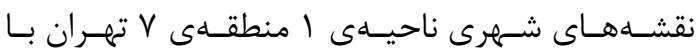

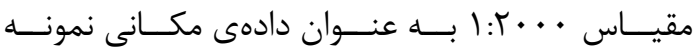

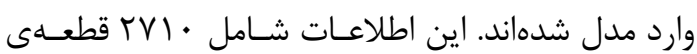

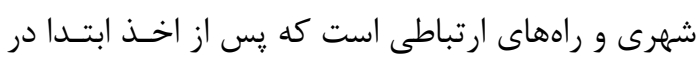

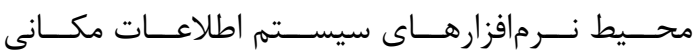
ويرايش شده و تمامى خطاهاى موجـود در آنهـا

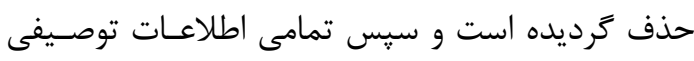

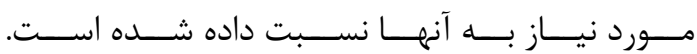

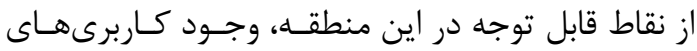
متنوع در سطوح مختلف مديريت شهرى اسـت كـه در

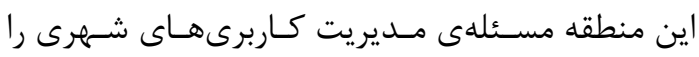
يبيجيده مى سازد. دادههاى اصلى مورد نياز بـراى ايجـاد يايخاه دادههاى مكانى در اين تحقيـق شـامل اطلاعـات

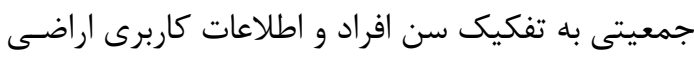

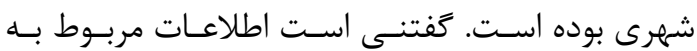

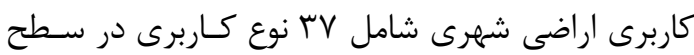
محله، منطقه و شهر مىباشد. شكل (r) محدودهى مطالعاتى تحقيق را نشان مى دهد. همانطور كه ملاحظه مسىشـود در ايـن شـكل قطعـات

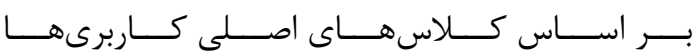

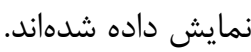

\section{r-r-r - تعريف توابع هدف}

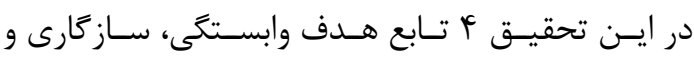

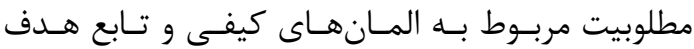

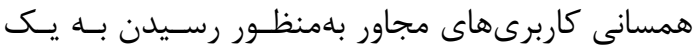

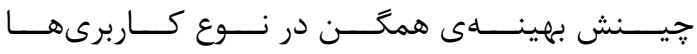
تعريف شده است كه در ادامـه بـه شـرح جزئيـات ايـن دهن توابع يرداخته خواهد شد.

\footnotetext{
${ }^{1}$ Geospatial Information Systems
}
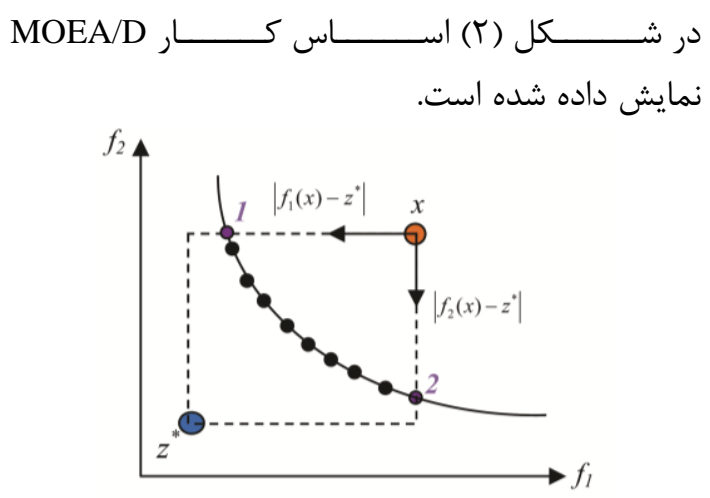

شكل r: تعبير مفهوم وزن در الكَوريتم MOEA/D يك جواب اوليه و f1 و f2 توابع هدف و أz تخمين جبههلى جواب بهينه است.

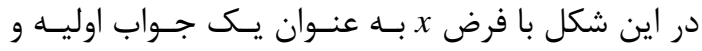
توابـع هــــ 年 $\left|f_{1}(x)-z^{*}\right|$ نقطهى xx از "z در جهـت محورهـا و تخمسين جبهـهـى جواب بهينـهـ اسـت. همـانطور كـه ملاحظـهـ مسىشـود، بردار وزن در نقطـهى ا، ( •و ا) و در نقطـهى كا، (او •)

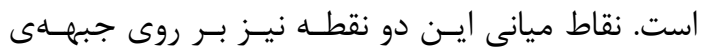

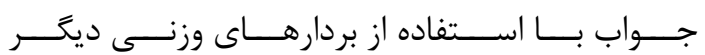
بلهدست مى آيند. در حقيقت نقش $\lambda$ در در اينجا جستجو

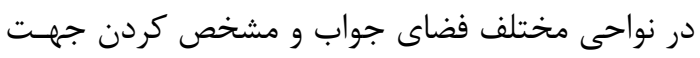
حركت به سمت نقطهى آرمانى است. بنابراين ورودى جنها

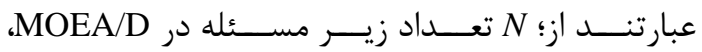
بردارهاى وزن

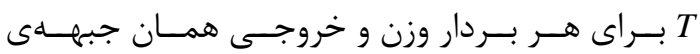

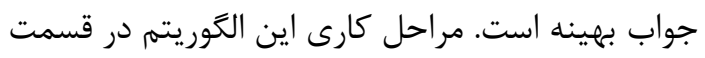
ييادهسازى و اجراى الكَوريتم آهده است.

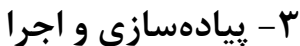

همانطور كه در قسمتهاى قبل نيز اشاره شد، مسئلهى

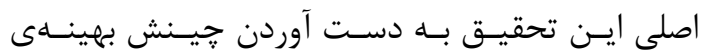

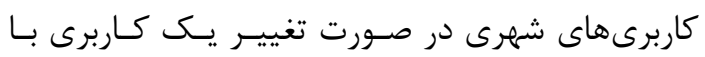

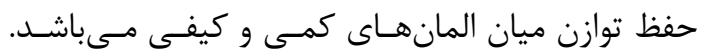

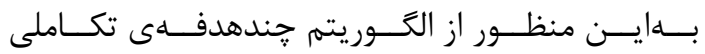
MOEA/D استفاده خواهد شد. در اين قسـمت مراحـل جنل 


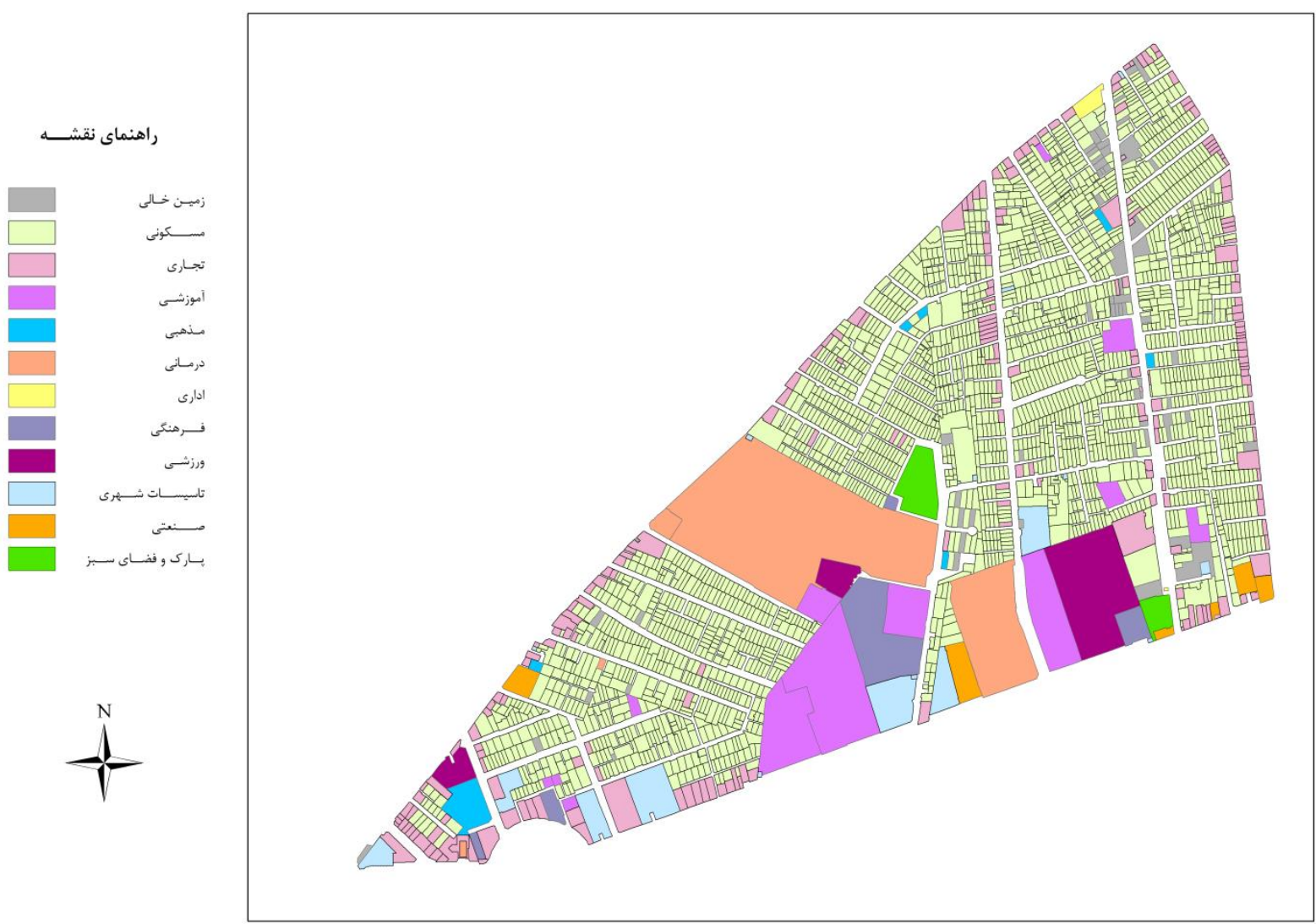

شكل זّ: منطقهى مطالعاتى و دستهبندى قطعات بر اساس كاربرىهاى اصلى آنها

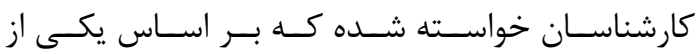

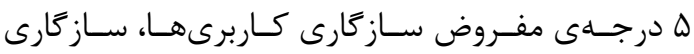

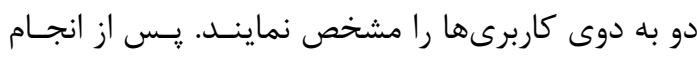

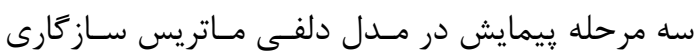

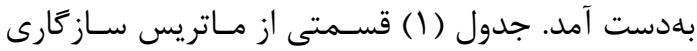

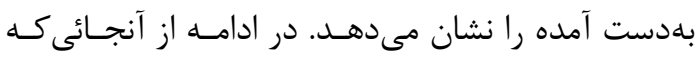

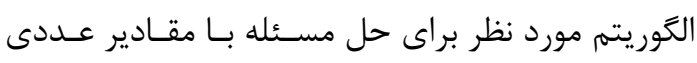

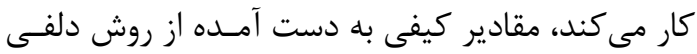

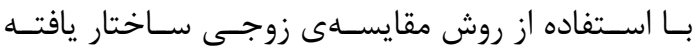

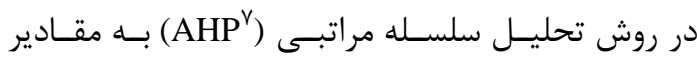
عددى تبديل شدهاند. اين مقادير براى سطوح سازكارى سارى

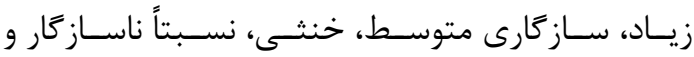

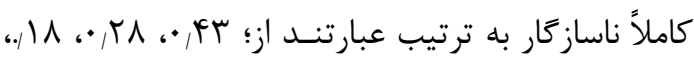

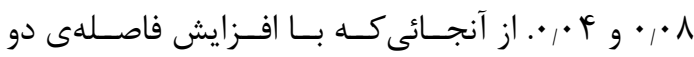

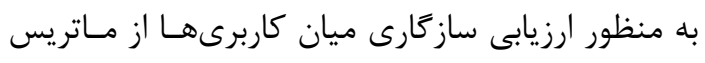

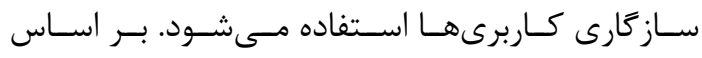
نظر كارشناسان سازگًارى در زينج سطح سـازكارى زيـاد

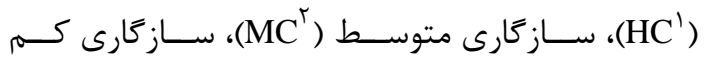

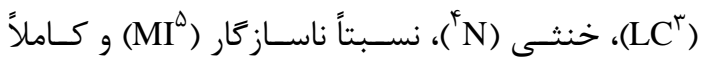

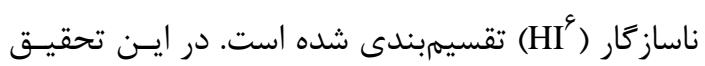

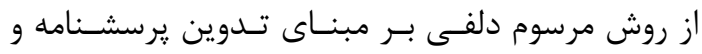

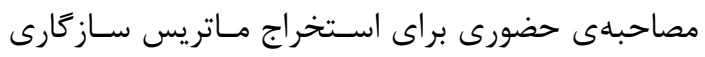

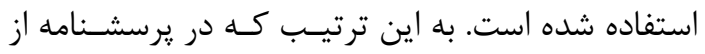

\footnotetext{
${ }^{1}$ High Consistancy

${ }^{2}$ Medium Consistancy

${ }^{3}$ Low Consistancy

${ }^{4}$ Neutral

${ }^{5}$ Medium Inconsistancy

${ }^{6}$ High Inconsistancy
} 


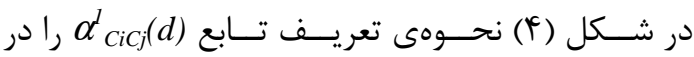

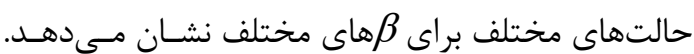

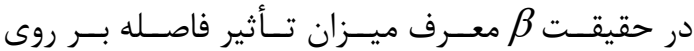
تابع است. در اين تحقيق براى سادگى محاسبات مقـدار 年

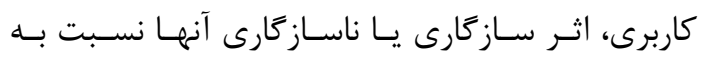

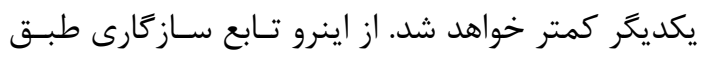
رابطه (f) تعريف شده است. رابطه (f)

$\operatorname{Comp}_{i j}=f_{2}\left(d_{i j}, C_{i} C_{j}\right)=f_{2}\left(d_{i j}, C M P_{c i c j}\right) \times \alpha_{C i, C j}^{l}\left(d_{i j}\right)$

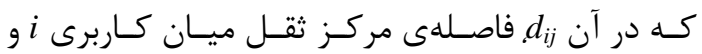
يارسل ز،

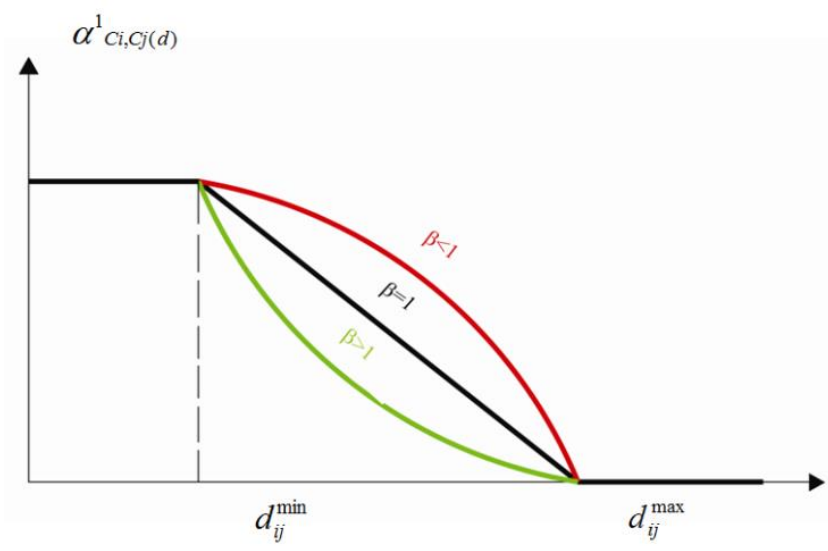

شكل f: نحوهى تأثير $\beta$ در تعريف تابع فاصله dij در نظر ترفته شده است و

رابطه (a)

$F_{2}: \operatorname{Maximize}\left(\frac{1}{n} \sum_{i=1}^{n}\left(\frac{1}{n_{i}} \sum_{j=1}^{n_{i}}\left(\operatorname{Comp}_{i j}\right)\right)+\underset{i j}{\operatorname{Min}}\left(\operatorname{Comp}_{i j}\right)\right)$ كــه در آن، $i$ نشــاندهندهى قطعـات، ز همســايههــاى

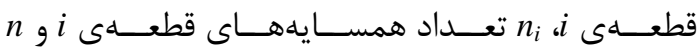

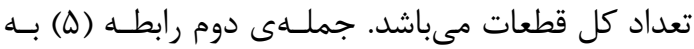

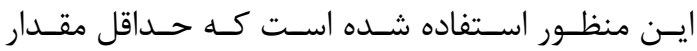

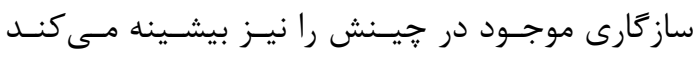
به اين ترتيب از جينشهـايى كـه در آنهـا يـك مقــدار

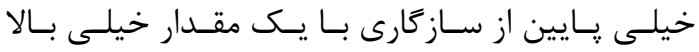
داراى ميانگين خوبى باشند، جلوَيرى مى شودا. بنابر اين

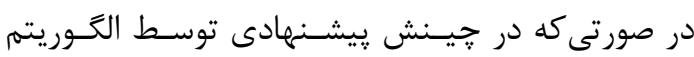

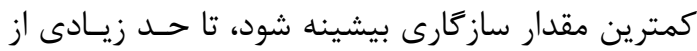
به وجود آمدن اين مشكل جلوكيرى خواهد شد.

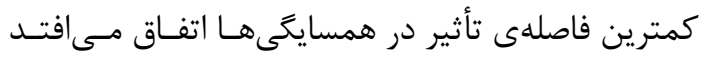

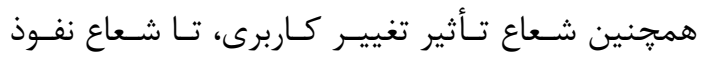
كاربرىهاى در نظر كرفته شده اسـت. هـر فعـاليتى در

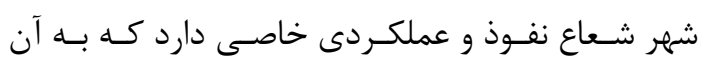

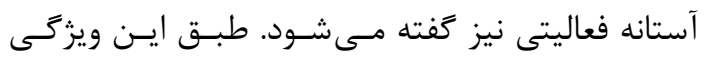

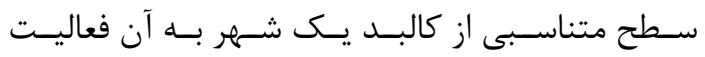

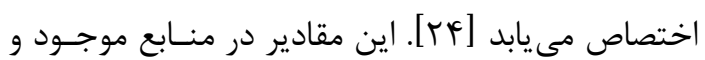

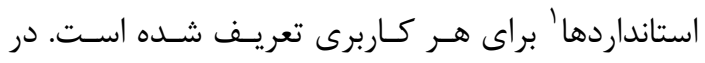

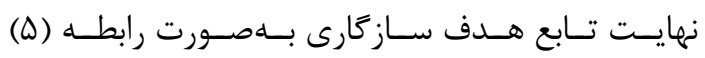
تعريف شده است.

\footnotetext{
'در مواردى كه در منابع موجود شعاع نفوذ براى كاربرى مورد نظر

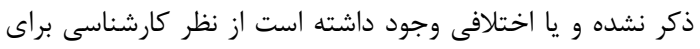
استخراج شعاع نفوذ استفاده شده است.
} 
جدول ا: بخشى از ماتريس سازگًارى استخراج شده از مدل دلفى

\begin{tabular}{|c|c|c|c|c|c|c|c|c|c|c|c|c|c|}
\hline \multicolumn{6}{|c|}{ آموزشى } & \multicolumn{3}{|c|}{ تجارى } & \multicolumn{3}{|c|}{ مسكونى } & \multirow{2}{*}{\multicolumn{2}{|c|}{ كاربرىها }} \\
\hline \multirow[t]{12}{*}{$\begin{array}{l}\frac{9}{\ddot{3}} \\
\ddot{10}\end{array}$} & $\begin{array}{l}9 \\
3 \\
3 \\
: 3\end{array}$ & \begin{tabular}{l}
3 \\
$\vdots$ \\
3 \\
$\vdots 3$ \\
\hdashline
\end{tabular} & $\begin{array}{l}\overline{9} \\
\frac{3}{3} \\
3\end{array}$ & $\begin{array}{l}3 \\
3 \\
3 \\
3\end{array}$ & $\begin{array}{l}3 \\
3 \\
y^{2} \\
y^{3}\end{array}$ & $\frac{3}{3}=\frac{9}{3}$ & $\frac{\beta}{3}$ & $\frac{2}{\frac{2}{3}}$ & $\begin{array}{l}\frac{5}{5} \\
\frac{2}{2}\end{array}$ & $\begin{array}{c}5 \\
5 \\
2 \\
3 \\
3 \\
3\end{array}$ & $\begin{array}{l}y_{2} \\
\frac{2}{5}\end{array}$ & & \\
\hline & & & & & & & & & & & $\mathrm{HC}$ & كمم تراكم & \multirow{3}{*}{ مسكونى } \\
\hline & & & & & & & & & & $\mathrm{HC}$ & $\mathrm{MC}$ & تراكم متوسط & \\
\hline & & & & & & & & & HI & $\mathrm{MC}$ & MI & تراكم بالا & \\
\hline & & & & & & & & $\mathrm{HC}$ & $\mathrm{HC}$ & $\mathrm{HC}$ & $\mathrm{HC}$ & |روزانه - هفتخى & \multirow{3}{*}{ تجارى } \\
\hline & & & & & & & $\mathrm{N}$ & $\mathrm{N}$ & $\mathrm{MC}$ & $\mathrm{MC}$ & $\mathrm{N}$ & |محله & \\
\hline & & & & & & $\mathrm{HC}$ & MI & $\mathrm{N}$ & $\mathrm{N}$ & $\mathrm{N}$ & $\mathrm{N}$ & |منطقه/ شهر & \\
\hline & & & & & HI & MI & $\mathrm{HC}$ & $\mathrm{HC}$ & $\mathrm{HC}$ & $\mathrm{HC}$ & $\mathrm{HC}$ & |مهد كودى & \multirow{6}{*}{ آموزشى } \\
\hline & & & & $\mathrm{HI}$ & $\mathrm{HC}$ & MI & $\mathrm{HC}$ & $\mathrm{HC}$ & $\mathrm{HC}$ & $\mathrm{HC}$ & $\mathrm{HC}$ & |دبستان & \\
\hline & & & HI & $\mathrm{HC}$ & $\mathrm{N}$ & MI & $\mathrm{HC}$ & $\mathrm{HC}$ & $\mathrm{HC}$ & $\mathrm{HC}$ & $\mathrm{HC}$ & راهنمايى & \\
\hline & & HI & $\mathrm{HC}$ & $\mathrm{N}$ & MI & $\mathrm{N}$ & $\mathrm{MC}$ & $\mathrm{MC}$ & $\mathrm{N}$ & $\mathrm{N}$ & MI & دبيرستان & \\
\hline & HI & $\mathrm{HC}$ & $\mathrm{N}$ & MI & MI & $\mathrm{HC}$ & $\mathrm{N}$ & $\mathrm{N}$ & MI & MI & MI & هنرستان & \\
\hline $\mathrm{HI}$ & $\mathrm{MC}$ & $\mathrm{MC}$ & $\mathrm{N}$ & MI & MI & $\mathrm{N}$ & MI & MI & MI & MI & $\mathrm{HI}$ & دانشعاه/دانشكده & \\
\hline
\end{tabular}

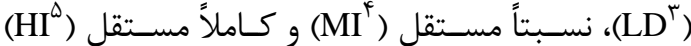
تقسيمبندى شـده اسـت. در اينجـا نيـز مقـادير كيفى

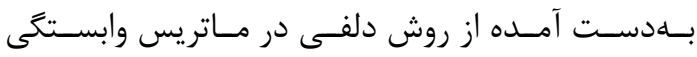
با استفاده از روش مقايسـهى زوجسى سـاختار يافتـه در

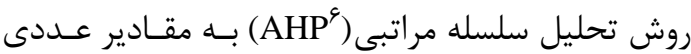

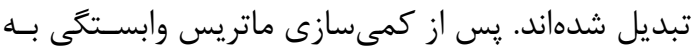
تعريف تابع هدف وابستخى يرداخته مىشود.

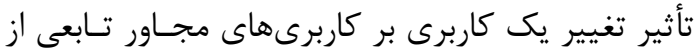

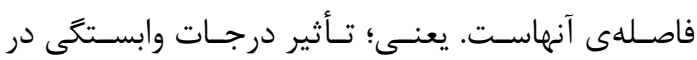

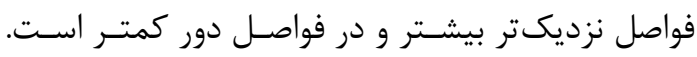

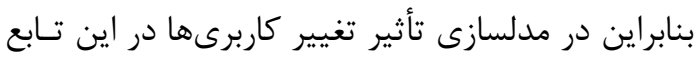

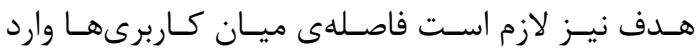

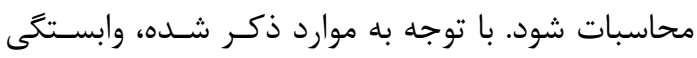

${ }^{3}$ Low Dependancy

${ }^{4}$ Medium Independant

${ }^{5}$ High Independant

${ }^{6}$ Analytical Hierarchical Process

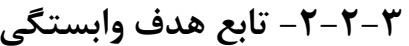

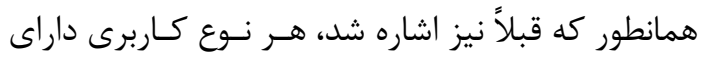

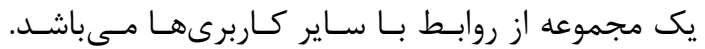
اين روابط تعريف كنندهى وابستكى هر كـاربرى نسـبت إنس

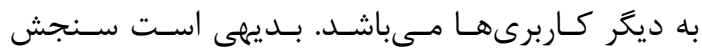
مقدار وابستخى بسيار مشكل است خراكسه بـه وسـيلهى

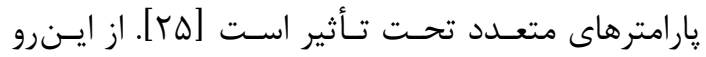
بلهمنظور مدلسازى وابستكى در بيشـتر تحقيقـات بــــاى

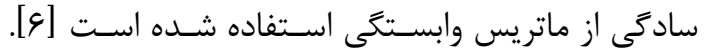
در تحقيق حاضر نيز براى مدلسازى وابستكى كاربرىها

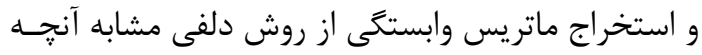

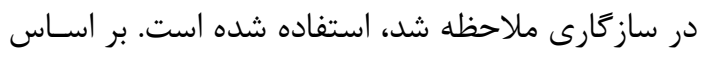
نظر كارشناسان وابستخى در رينج سطح وابستتخى زيـاد

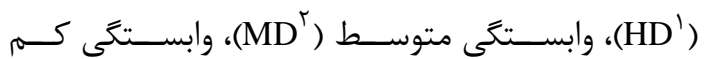

\footnotetext{
${ }^{1}$ High Dependancy

${ }^{2}$ Medium Dependancy
} 
كه در آن DEP كاربرى در ماتريس وابستخى و

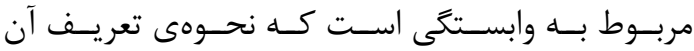

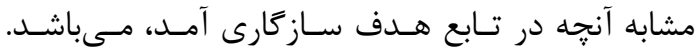

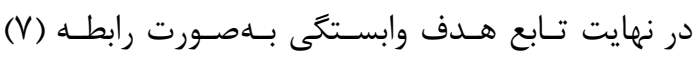
تعريف شده است؛

$$
F_{2}: \operatorname{Maximize}\left(\frac{1}{n} \sum_{i=1}^{n}\left(\frac{1}{n_{i}} \sum_{j=1}^{n_{i}}\left(\operatorname{Dep}_{i j}\right)\right)+\operatorname{Min}_{i j}\left(\operatorname{Dep}_{i j}\right)\right)
$$

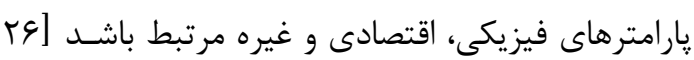

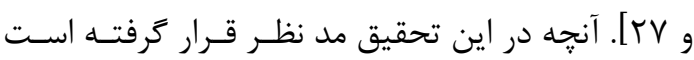

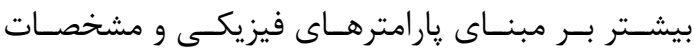
ظاهرى قطعه زمين مىباشد. بنابراين با مطالعهى منــابع و مستندات موجود و با استفاده از نظر متخصصان، تـابع هدف مناسبت بهصورت رابطه (^) تعريف شده است.

$$
S_{j, C i}=w_{1} A_{j, C i}+w_{2} A c_{j, C i}+w_{3} E d_{j, C i}+w_{4} V P_{j, C i}+w_{5} A p_{j, C i}+w_{6} R_{j, C i}
$$

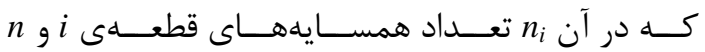
تعداد كل قطعات مىباشد.

\section{r-r-r-r- تابع هدف مناسبت كاربرى با زمين}

منظور از اين تابع هدف، مناسب بودن قطعه زمين براى استقرار يك كاربرى مشخص در آن مسىباشـــ بنـابراين

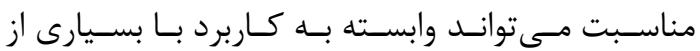

در نهايست تـابع هـــف سـوم بـهـهـورت رابطــهـ (• (1) تعريف شده است.

رابطه (•) (1)

$F_{3}: \operatorname{Maximize}\left(\sum_{i=1}^{n} \frac{1}{n} S_{i, C i}+\operatorname{Minimmum}\left(S_{i, C_{i}}\right)\right)$

كه در آن Si, Ci مناسـبت كـاربرى iC

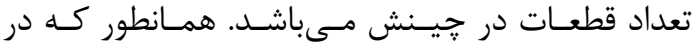
رابطه (9) ملاحظه مسىشـود، در ايـن تـابع هـدف نيـز

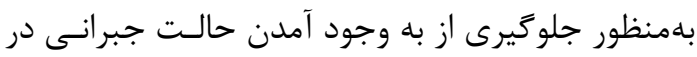

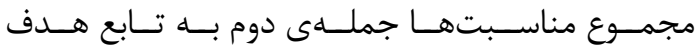

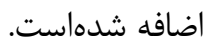
جدول r: وزندهى نهايى به المانهاى در نظر كرفته شده

\begin{tabular}{|c|c|}
\hline وزن - ان & عامل در نظر گرفته شده \\
\hline$\%$ \% & مساحت \\
\hline$\%$. & دسترسى \\
\hline$\%$ & تعداد برها \\
\hline$\% 1 \mathrm{~V}$ & آلودكى هوا \\
\hline$\% 19$ & آلودگى صوتى \\
\hline$\% 10$ & سختى تغيير \\
\hline
\end{tabular}
براى مناسبت در تحقيق با توجه به نظر كارشناسى
كه در آن A A A A

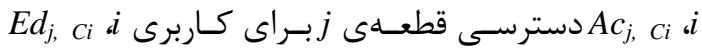
مناسبت تعداد برهاى قطعهى ز براى كـاربرى

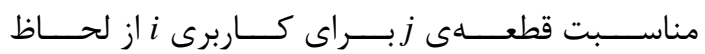
آلودگى صوتى، AP A A

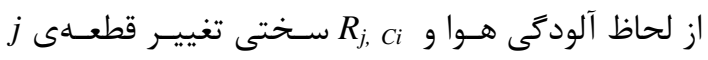
به كاربرى i أ مى باشد.

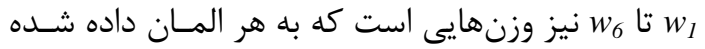

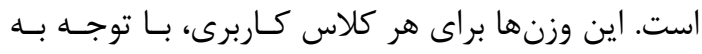

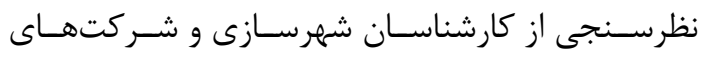

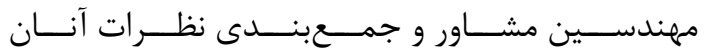

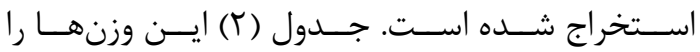
نشان مىدهد. همجنين براى راحتى محاسـبات تمـامى

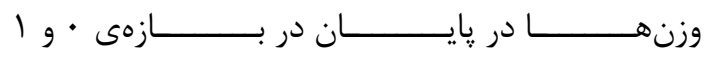

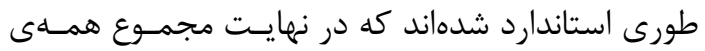
آنها برابر ا باشد. به عبارت ديخر طبق رابطه (9)؛ $\sum_{i=1}^{6} w_{i}=1$

(9) رابطه 
و معمارى ايران در سال 91٪ 1،، طرح جامع سـاماندهى

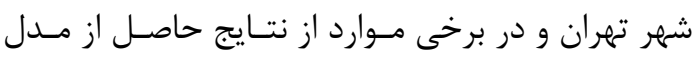
دلفى استفاده شده است.

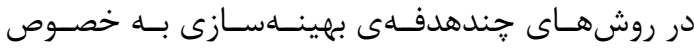

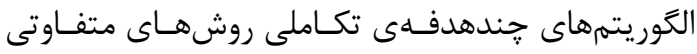
براى برخورد با شرايط مسئله ذكر شده اسـت [IV] اينجا از روش مبتنى بر تابع جريمه به علـت سـادگى و

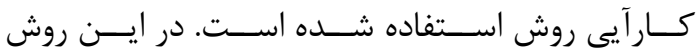
يكى عبارت جريمه، به جريمه كردن جوابهاى ناموجـهـ

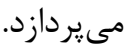
بهمنظور ورود سرانه به مدل، سرانهى هر كلاس كاربرى با شرط رابطه (T) I Iارد مسئله مىشوند. $P_{c, \min } \leq P_{c} \leq P_{c, \max }$

(ابطه (T)

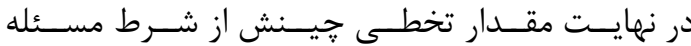

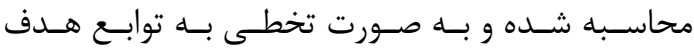

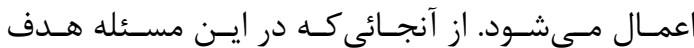

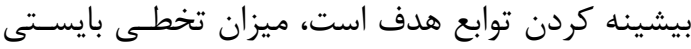
بلهصورت يك عامل كاهنده به توابع هدف اعمـال شـود.

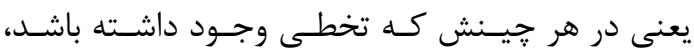
ضريبى كاهشى به توابع هدف اعمال مى كـردد و مقــدار

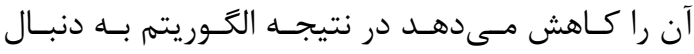

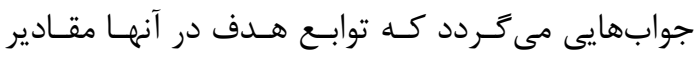

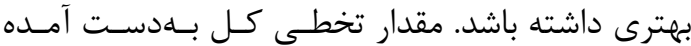

بلصورت رابطه (ب ا) به توابع هدف اعمال مىشود. $\hat{F}=\frac{F}{1+W \bar{V}}$

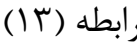

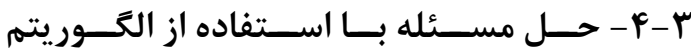

MOEA/D

همانطور كـه در بخـش دوم كَفتـه شــ، ايـن الحَـوريتهم بر اساس تجزيهى مسئلهى جندهدفه به زيرمسئلههـاى تك هدفه عمل مى كنـد. ورودىهـاى روش MOEA/D

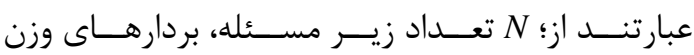
ئ بردار وزن. در ذيل نحوهى تعريف هر يك ازئ اين ائ المانها در مسئله آمده است.

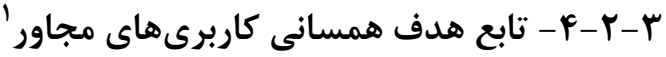

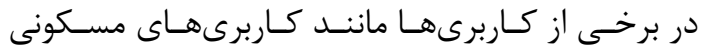

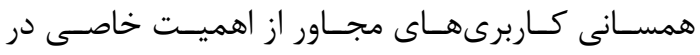

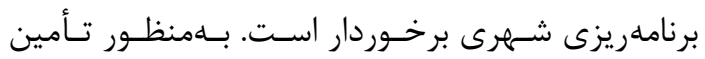

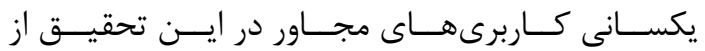

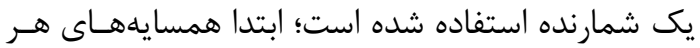

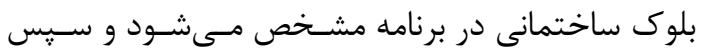

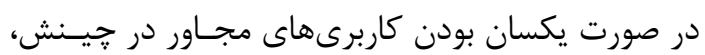

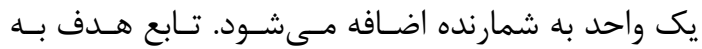

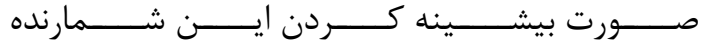

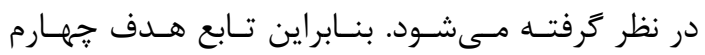
بلهورت رابطه (1) تعريف شده است. رابطه (1) كه در آن عبارت Compactness شمارندهى مربـوط بـهـ همسانى كاربرىهاى مجاور است. r-r- - r- شرط مسئله

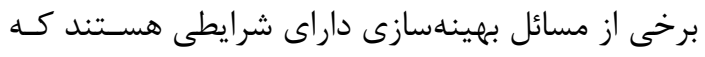

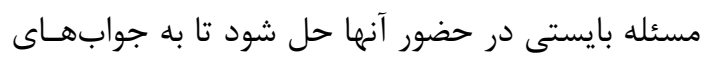
قابل قبـولى در فضـاى جسـتجو دسـت يافتـ در ايــن

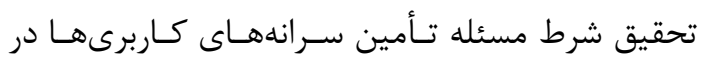

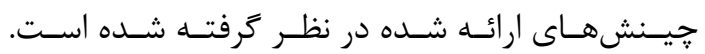
اين شاخص توسط برنامـهـريـزان بــراى تعيـين كمبــود

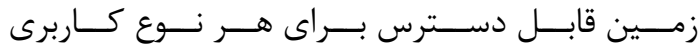

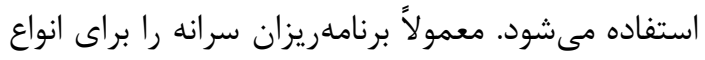

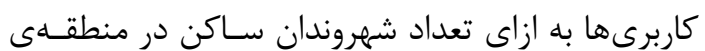
مورد مطالعه، محاسبه كرده و با مقايسهى آن با مقــادير هدف ذكر شده در استاندارد حداقل خدمات، مشككلات و كمبودهاى موجود در اين خصوص را نمايش مى دهند

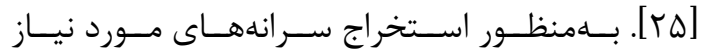

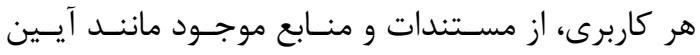

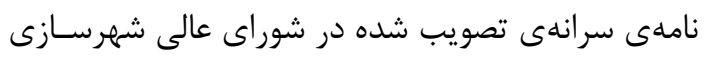

${ }^{1}$ Compactness 
ولى در فرزندان توليد شده كاربرى مسكونى در

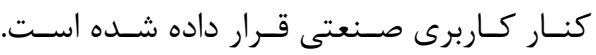

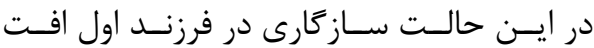

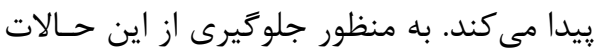

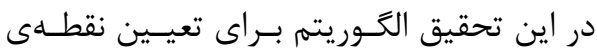

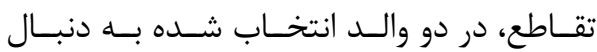

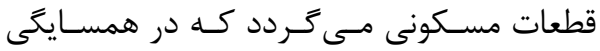

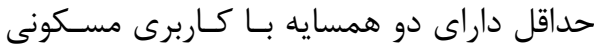
باشند (بـهدليـل حفـظ همخـونى كـاربرىهـاى داي مجاور). سيس بلهـورت تصـادفى، تقـاطع را از موقعيت يكى از اين نقاط انجام مى دهد. لازم به

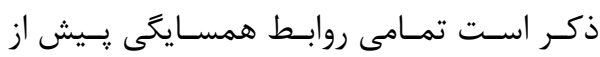

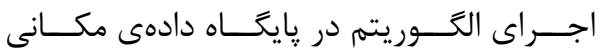

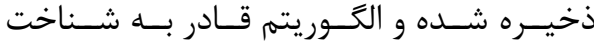

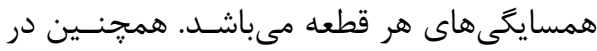

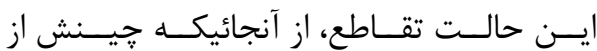
ناحيهاى شكسته مىشـود كـهـ نــوع كـاربرىهـا

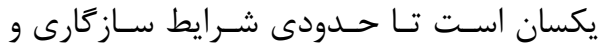
وابستكى نيز حفظ مىشود زيرا در خينش والد،

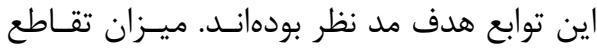
در اين تحقيق 9 •• در نظر گرفته شده است.

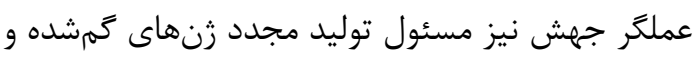

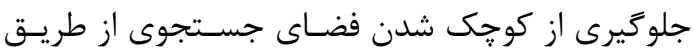

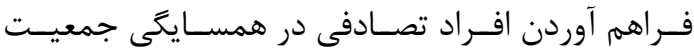

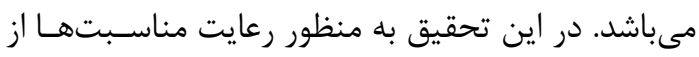
روش خاصى از جهش استفاده شده است. در ايـن روش

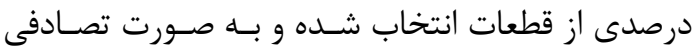

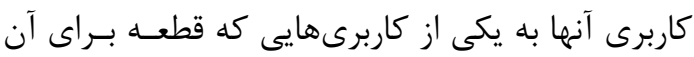

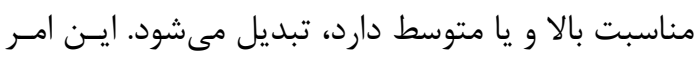

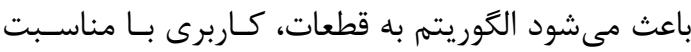

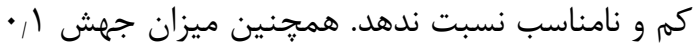
در نظر كرفته شده است.

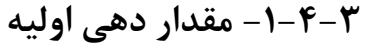

در ابتدا مجموعلى مربوط به جبهلهى جوابهـاى بهينه تهى در نظر كرفته مىشود ((E)

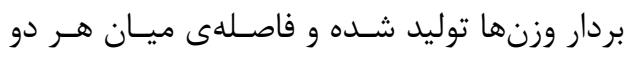
بردار وزنى محاسبه مىشود و سيس T همسايهى نزديكتر براى هر بردار به دست مى آيد.

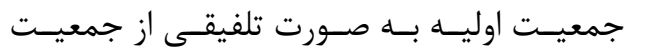

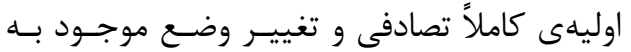
اندازمى • ب درصد، توليد مىشود.

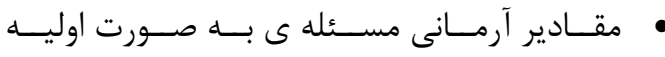
مشخص مىشوند. در اين مسئله بهتـرين مقــادير

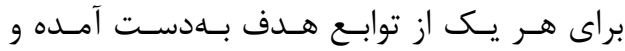
بهنوان مقادير آرمانى ذخيره مىشوند. r-Y-Y-r

•توليــد مجـــد: دو انــدكس k و 1 بــهـ صــورت تصادفى از مجموعهى همسايكىها انتخاب شده

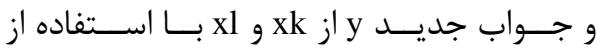

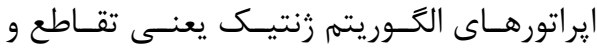

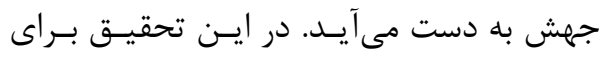

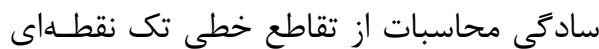
استفاده شده است. علاقمندان بـراى مطالعهىى بيشتر در مورد روشهاى تقاطع مسىتوانتــد بــهـ

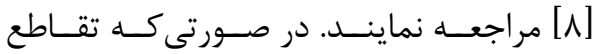
بهصورت كاملاً تصادفى انجام يذيرد، امكان دارد حالت يراكندگى در جينشهاى بلهدست آمــده

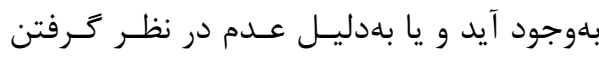
همسايكى، تينشها مقدار مناسب توابع هـدف را نداشته باشند. بهعـــوان مثـال در شـكل (a)

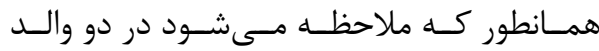
انتخاب شده براى تقاطع، سازكارى قابل قبـولى ميان كاربرىها در نقطـهـى تقـاطع وجــود دارد 


\begin{tabular}{|c|c|c|c|c|c|}
\hline & & \multicolumn{2}{|c|}{ محل انجام تقاطع در والدها } & & \\
\hline$C_{k-2}$ & $C_{k-1}$ & صنعتى & تأسيسات شهرى & $C_{k+2}$ & $\ldots$ \\
\hline \multicolumn{6}{|c|}{ I } \\
\hline$C_{k-2}$ & $C_{k-1}$ & تجارى & مسكونى & $C_{k+2}$ & ... \\
\hline & & \multicolumn{2}{|c|}{ i } & & \\
\hline & & \multicolumn{2}{|c|}{ فرزندان توليد شده } & & \\
\hline$C_{k-2}$ & $C_{k-1}$ & صنعتى & مسكونى & $C_{k+2}$ & $\ldots$ \\
\hline$C_{k-2}$ & $C_{k-1}$ & تجارى & تأسيسات شهرى & $C_{k+2}$ & $\ldots$ \\
\hline
\end{tabular}

\section{شكل ه: يكى مثال از تقاطع تصادفى بر روى والدها}

محله با كمبود اساسـى مواجـهـ اسـت. بـهـ ايسن منظـور

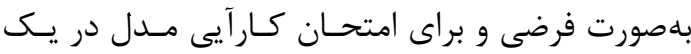

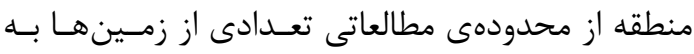
اين كاربرى اختصاص داده شـده اسـت تـا تـأثير تغييـر آنها بر جينش ساير كاربرىها بررسى شود. اين منطقه

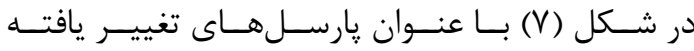

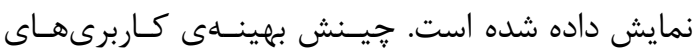

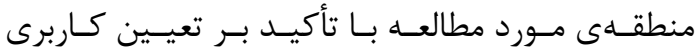

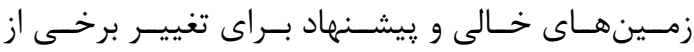

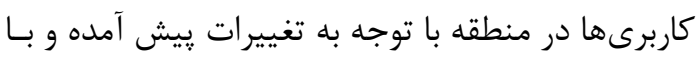

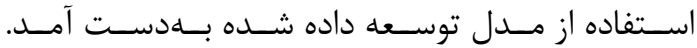

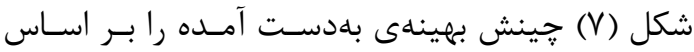

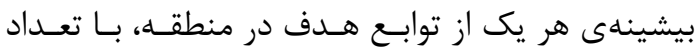

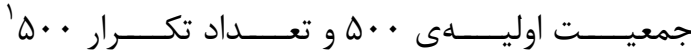
نشان مى دهد. كفتنى است در اين شكل بـراى سـهولت

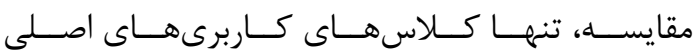
آورده شده است. همجنــين تمـامى مقـادير مربـوط بــهـ توابع هدف ميان • و 1 استاندارد شدهاند.

'انتخاب تكرار • له و جمعيت اوليهى . .له به اين دليل است كـه

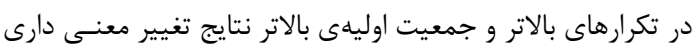

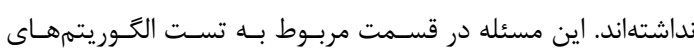
مدرن بيشتر تشريح شده است.
به روز رسانى مقادير آرمانى: در صورت بهتر بودن

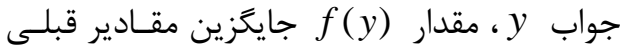
مىشود. •به روز رسانى جبهلى جوابهــاى بهينـه: مقـادير

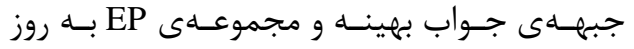
رسانى مىشوند. يعنى از EP تمامى بردارهايى كه

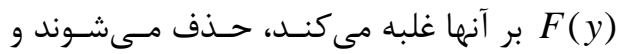
در صورتى كه (y) F(y توسط هيج يـك از اعضـاى غلبه نشود وارد اين مجموعه مىشود. EP r-r-r-r - بر در صــورت محقـق شـدن شــرايط خاتمـهـى الخَـوريتمه،

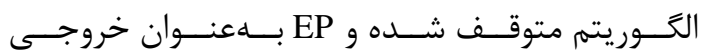
ذخيره مىشود. در غير اينصورت الخوريتم به مرحلـهى به روز رسانى مقادير باز مى

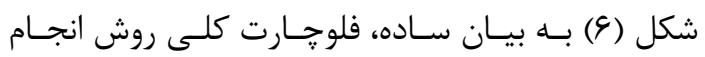
MOEA/D

F - نتايج حاصل از ييادهسازى مدل در اين قسمت به تشريح نتايج حاصل از مدلسـازى اثـر تغيير كاربرىهاى شهرى با استفاده از روش بهينهسازى جندهدفهى MOEA/D يرداخته مىشود. طبق بررسى هاى انجـام شـده بـهمنظـور تـدوين طـرح تفضيلى در محلههـاى انتخـاب شـده، كـاربرى تجـارى 


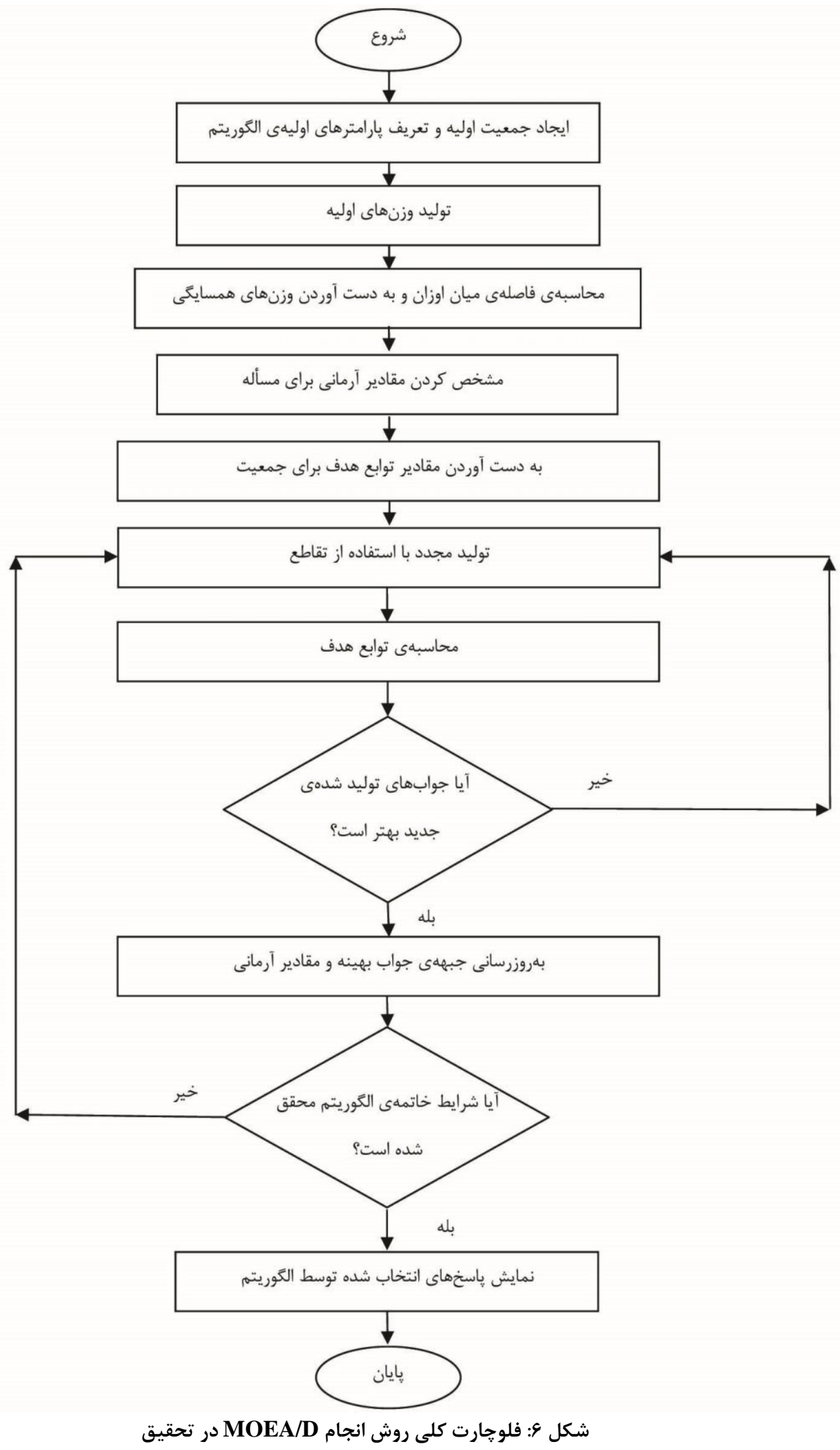



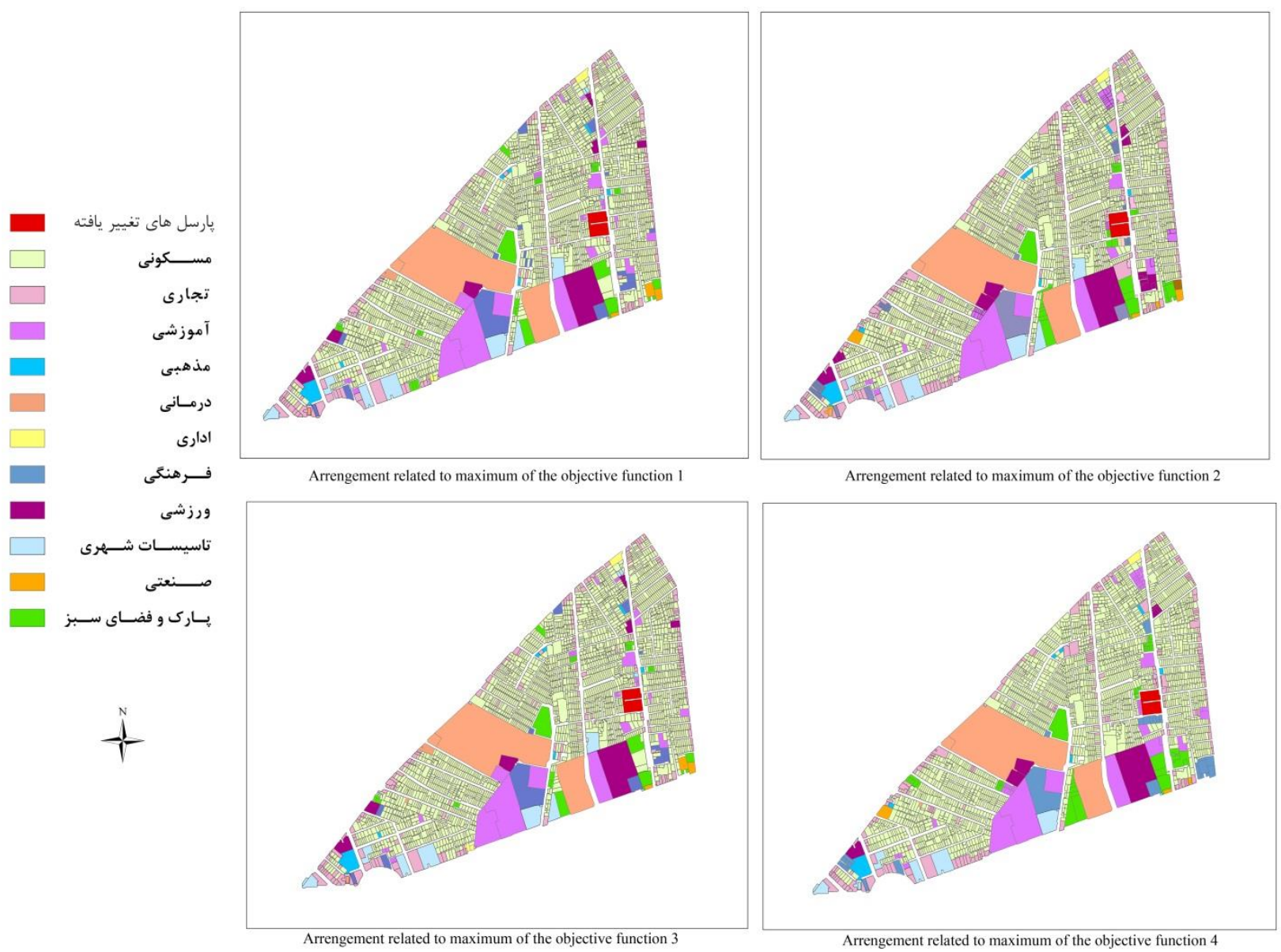

شكل V: جينش بهينهى به دست آمده بر اساس بيشينهى هر يك از توابع هدف با استفاده از روش MOEA/D

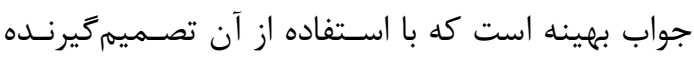

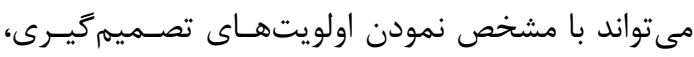
جينش متناظر را ملاحظه كند.

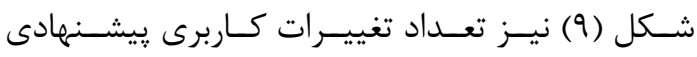

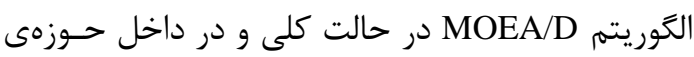
نفوذ كاربرى تغيير داده شده براى هر يك از حالتهايى كه توابع هدف بيشينه هستند را نشان مى دهدي.

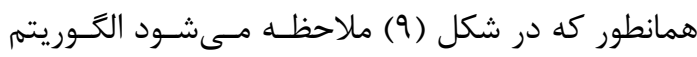

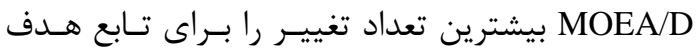

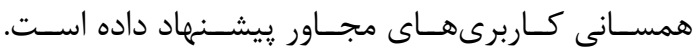
در حقيقت براى رسيدن به بيشينهى ايـن تـابع هـدف،

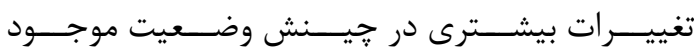
با استفاده از اين الكوريتم لازم است.

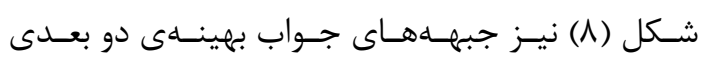
متناظر با توابع هدف را بـا اسـتفاده از روش نشان مى دهد. مسئلهى مفروض داراى جهار تابع هـدف

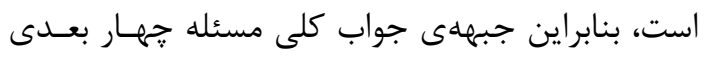

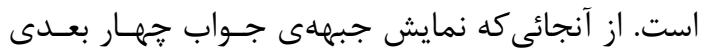

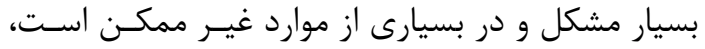

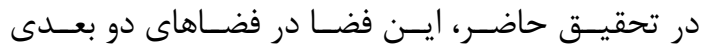
تصوير شده و نتايج نمايش داده شدهاند.

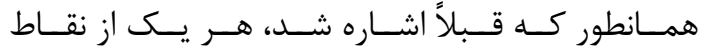
نمايش داده شده در شكل (^) يك جينش را در فضـاى

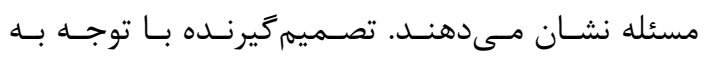

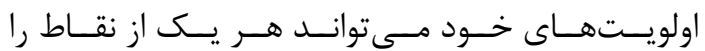

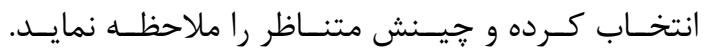
بنابراين يكى از مهمترين خروجىهاى تحقيق جبهـهـى 


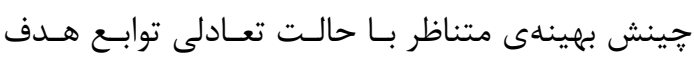
داراى كمترين تغييرات است.

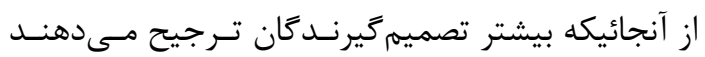

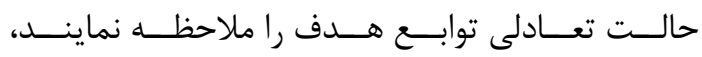

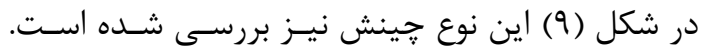
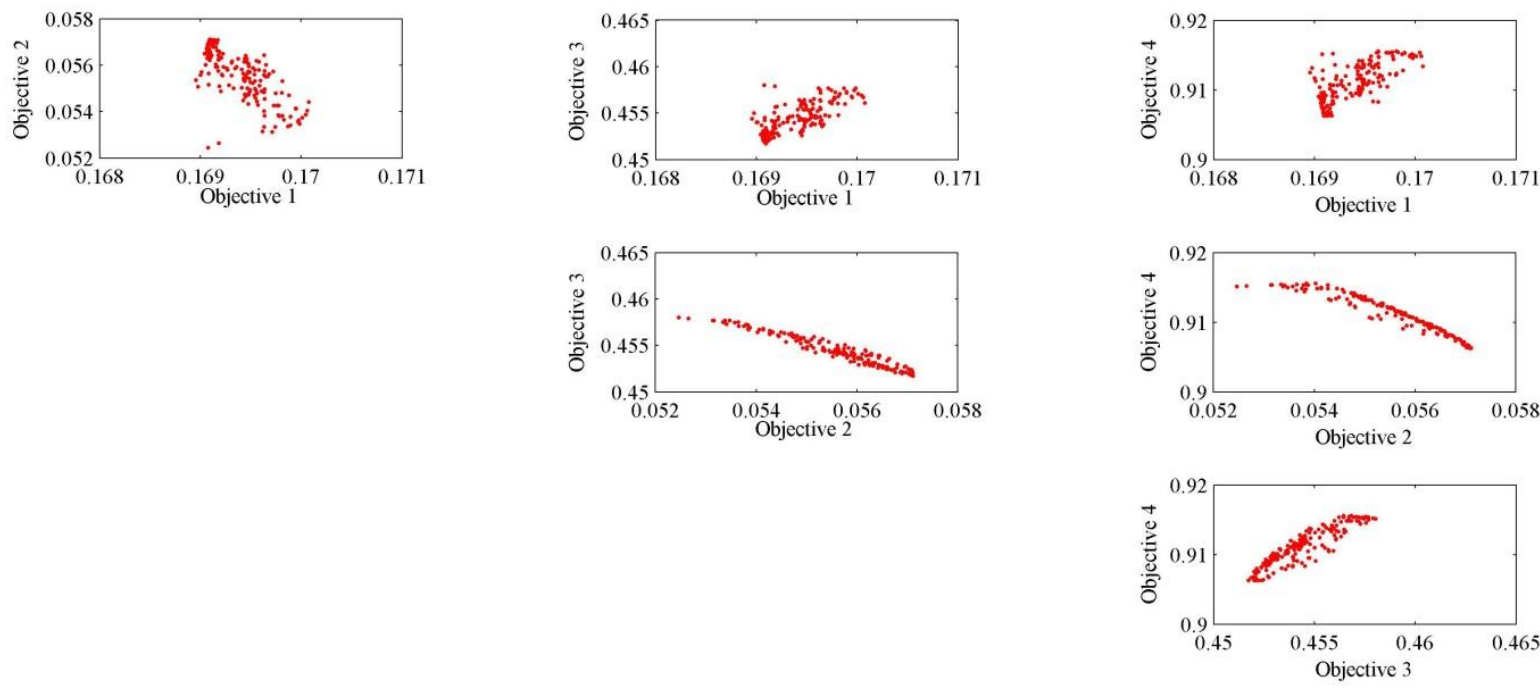

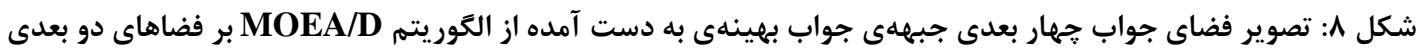

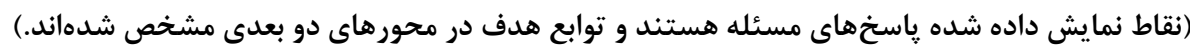

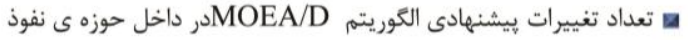
a تعداد تغييرات بيشنهادى الكوريتم MOEA/Dدر كل منطقه

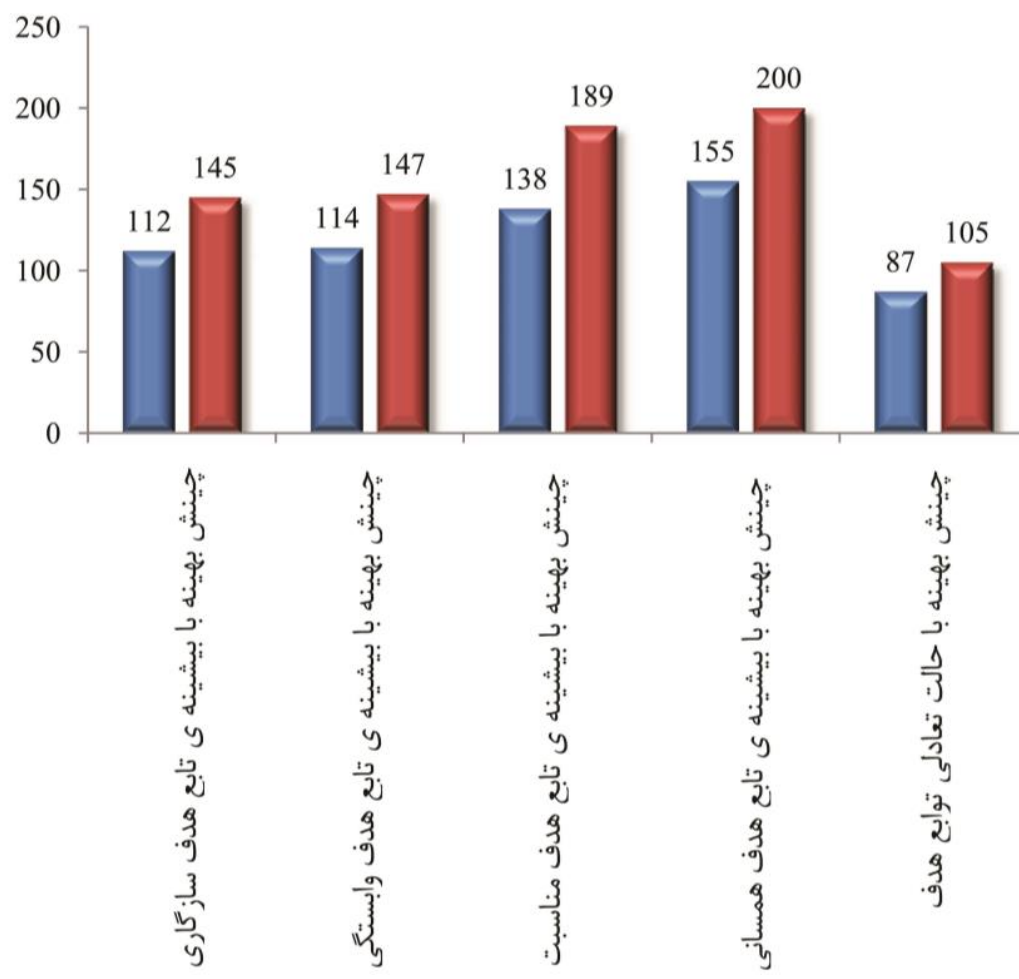

شكل 9: تعداد تغييرات كاربرى ييشنهادى الكَور يته MOEA/D در كل منطقه و در داخل حوزهى نفوذ براى هر يك از حالتهاى بيشينهى توابع هدف 

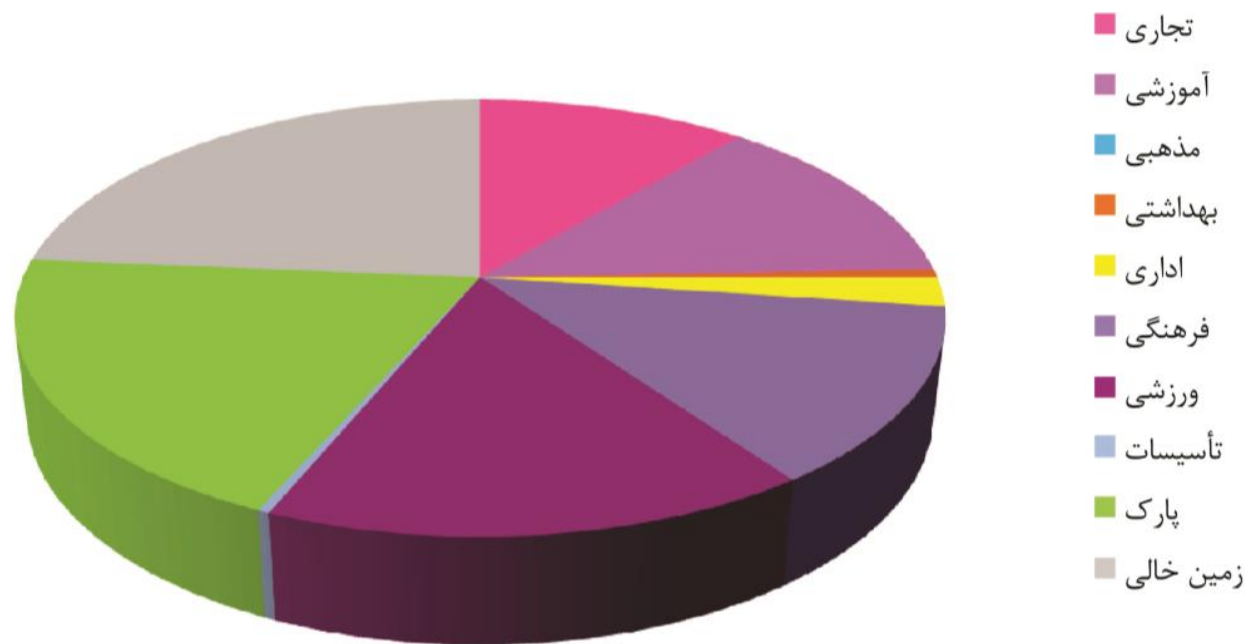

شكل ll: ميزان تغيير نوع كاربرىها در جينش بهينهى بهدست آمده در پاسخ به تغيير كاربرى به وجود آمده

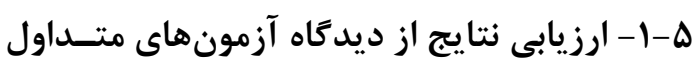

الخَوريتمهاى جندهدفه

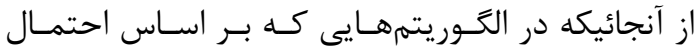

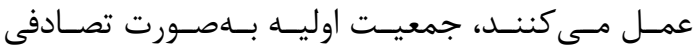

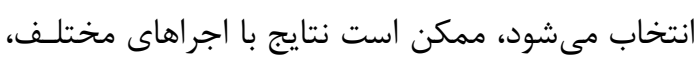

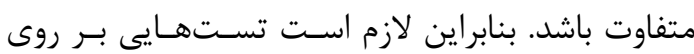

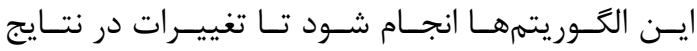
ملاحظه شده و ثبات الكوريتم بررسى شـود. البتـهـ لازم

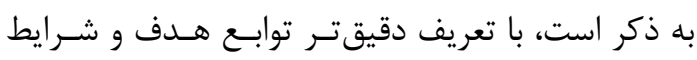
مسئله و نيز يارامترهاى اجرايى الكوريتم مى توان تا حد زيادى اين مسئله را كنترل كرد. از جملهى اين تستهاي

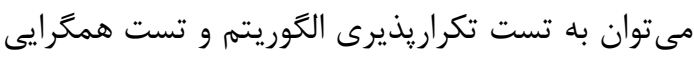

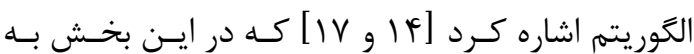
بررسى نتايج حاصل از اين تستها يرداخته خواهد شد.

$$
\text { ه-1-1- تست تكراريذيرى الكوريتم }
$$

براى انجام تست تكراريذيرى، الكَوريتهم با جمعيت اوليسه

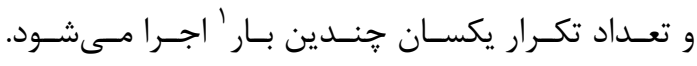

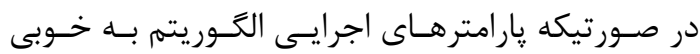

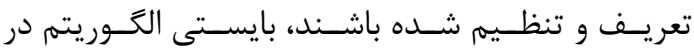

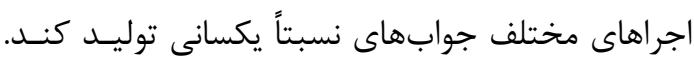

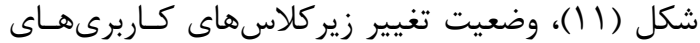
اصلى از نظر مساحت اختصاص داده شده در مقايسه بـا

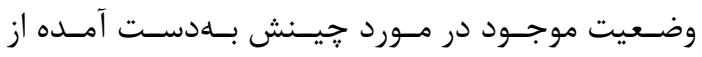
الكوريتم MOEA/D براى حالت بيشينهى سـازگًارى را

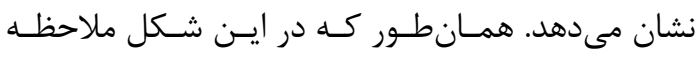

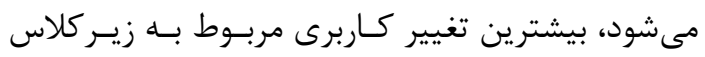
مسكونى كم تراكم و زمينهاى خالى است. اين مسـئله

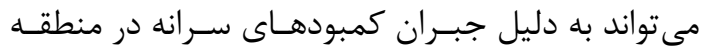
بر روى اين نوع كاربرى باشد. از طرفى سـختى تغييـر

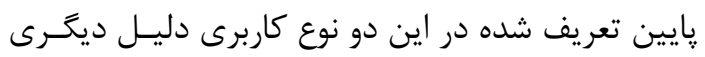
بر اين مسئله است. بنابراين المان سختى تغيير در تابع هدف مناسبت به وضوح در نتايج تأثير گذار است.

$$
\text { ه- ارزيابى نتايج }
$$

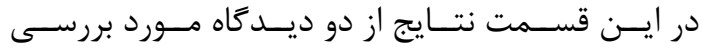

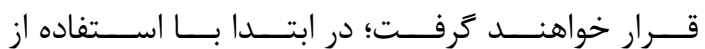

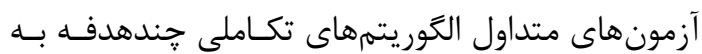

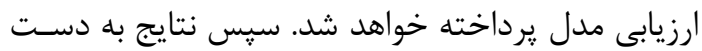

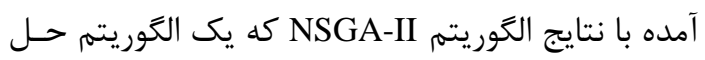
مسائل بهينهسازى جندهدفه بر مبناى الگوريتم زنتيـك ئه است، مقايسه خواهد شد. 
بررسى دقيقتر اين مسئله توليد شده است كـه درصـــ

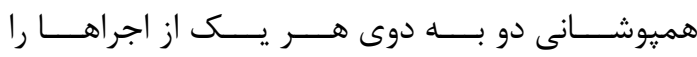

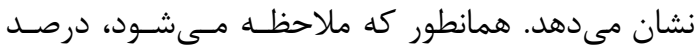

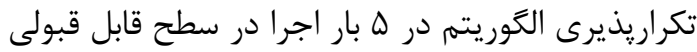

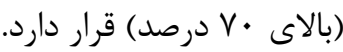

در صورتيكه حدود • V درصد جـوابهــا مشـابه باشـنـد

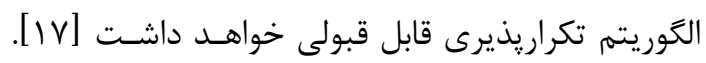

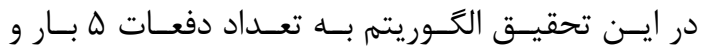

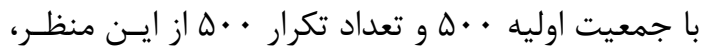

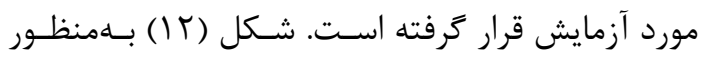

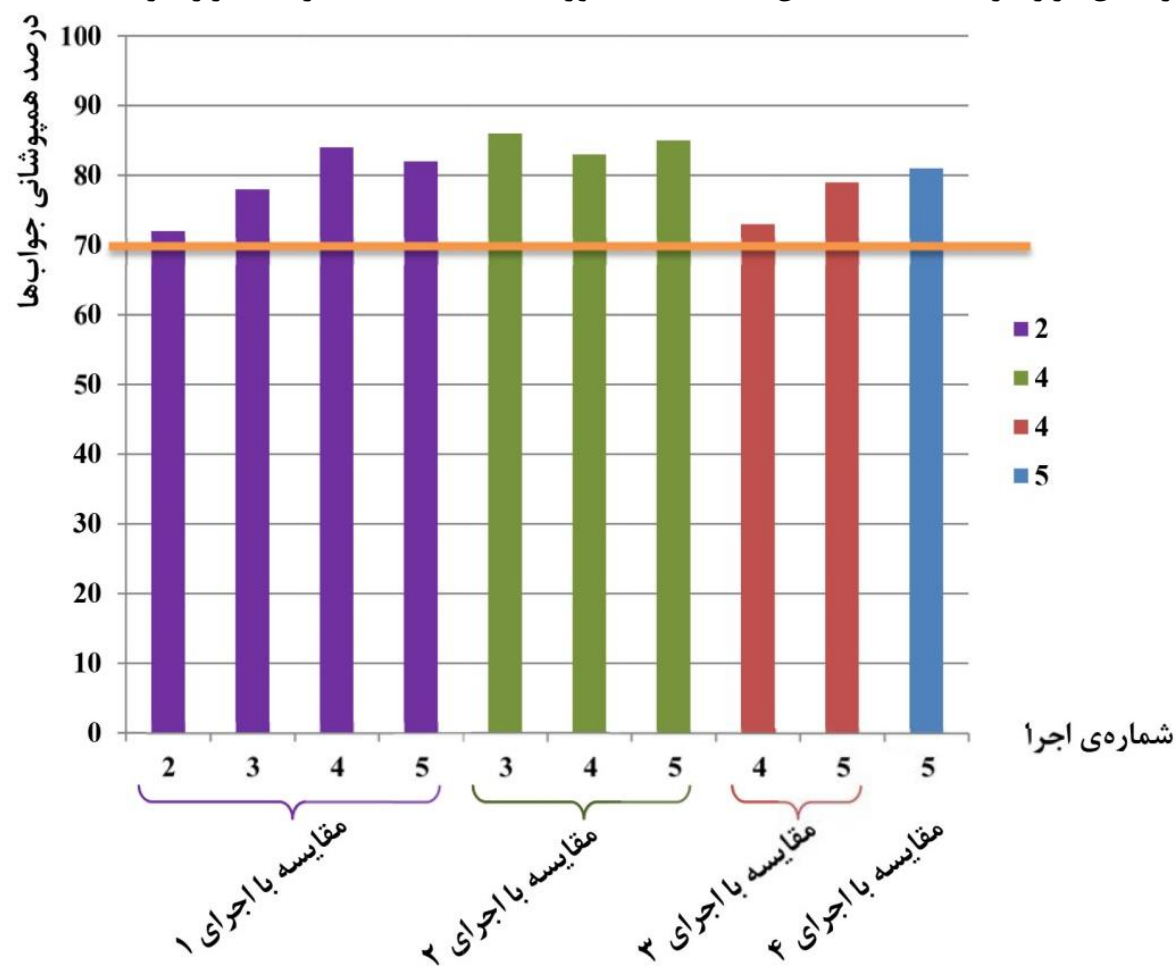

شكل rا: مقايسهى دو به دوى درصد هميوشانى جوابها در ه بار اجراى الكوريتم MOEA/D

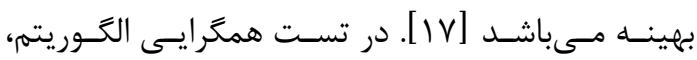
تغيير بيشينهى مقادير توابع هدف و تغييرات در تعـداد

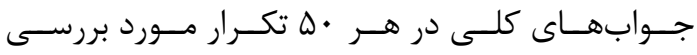

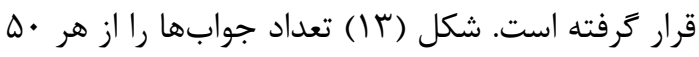

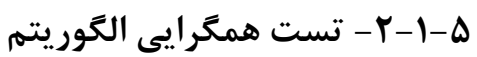

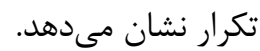

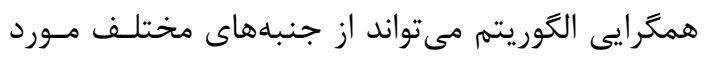

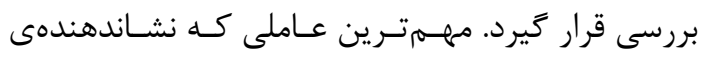

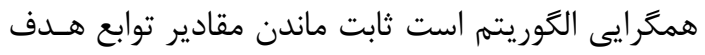

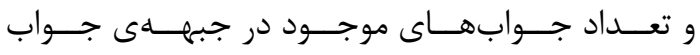

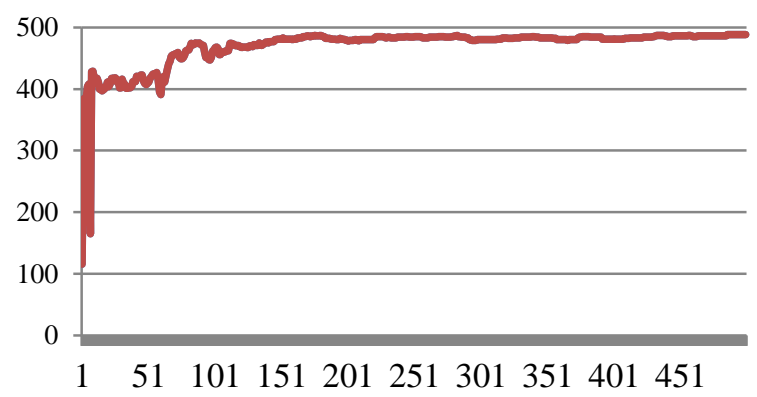

MOEA/D شكل זا: تغيير تعداد جواب در هر •ه تكرار در الكوريتم 


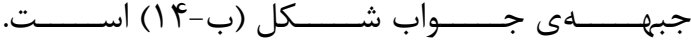

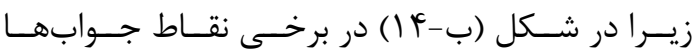

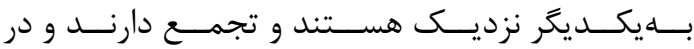
برخى مناطق فضاى خالى ميان جوابها وجود دارد.

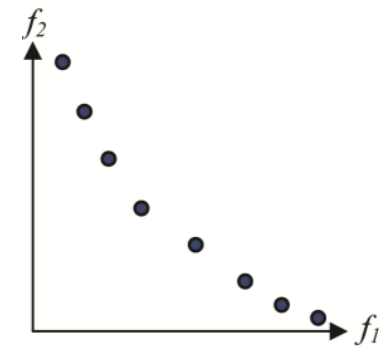

(الف)

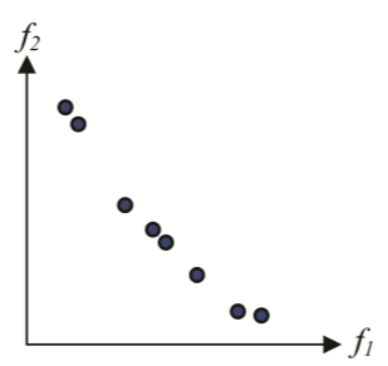

(ب)

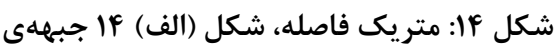

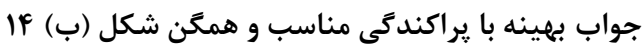
جبهلى جواب بهينه با يراكندكى نامناسب

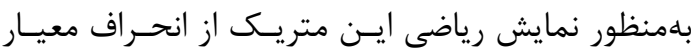
موجود در كمترين فواصل جوابهـا اسـتفاده مسىشـود.

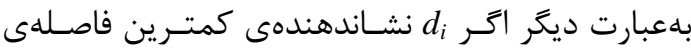

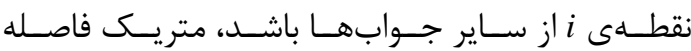

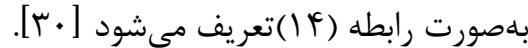
$S M=\sqrt{\frac{1}{n-1} \sum_{i=1}^{n}\left(d_{i}-\bar{d}\right)^{2}} \quad$ (I F) كــه در آن، n تعـداد نقـاط جبهـهـى جـواب بهينـهـ،

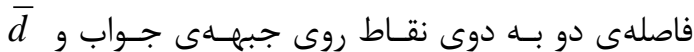

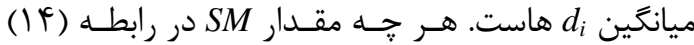

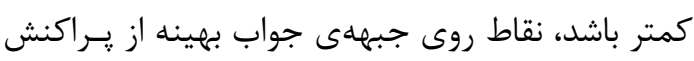

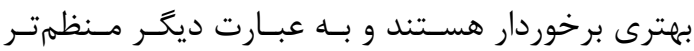
هستند.
همـانطور كـهـ در شـكل (با () ديــده مسىشـود، تعـداد جوابها در ابتدا متغير است و سيس با افزايش تكرارهـا

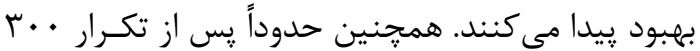

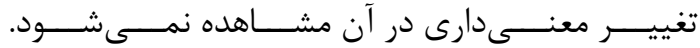

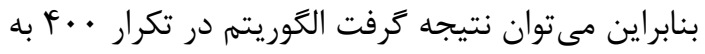

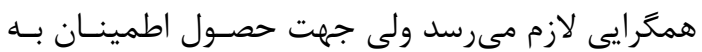

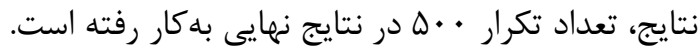

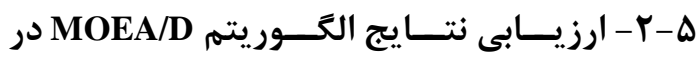
مقايسه با الكوريته NSGA-II

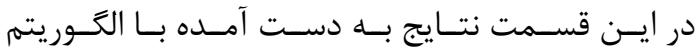
MOEA/D با نتايج الكوريتم NSGA-II كه با المانهاى زير اجرا شده است، مقايسه خواهد شد. از آنجائيكهـ در

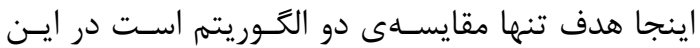

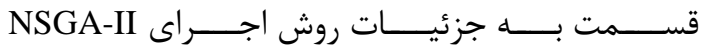
يرداخته نمىشود. علاقمندان براى كسـب اطلاعـات در

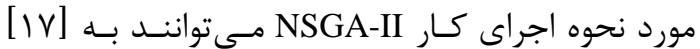

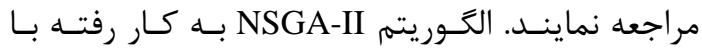
ايراتورهاى تقاطع و جهش و نيز جمعيت اوليهى كـاملاً يكسان با الكوريتم NSGA-II انجام شده است. با توجه به بررسى منـابع و مراجـع موجـود دو متريـك

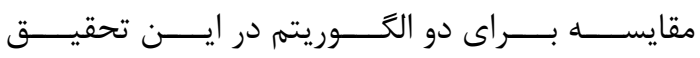

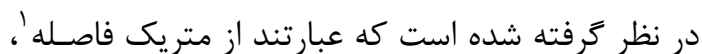

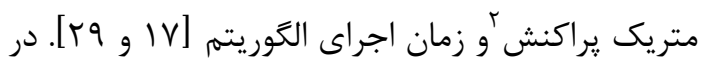
ذيل به بررسى جزئيات اين متريكها ير يرداخته مىشودا

ه-r-|- ا- متريك فاصله

با استفاده از اين معيار مىتوان براكندكى نقاط جبهله

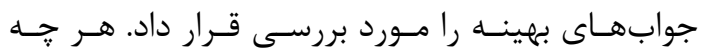

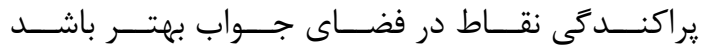

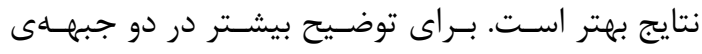

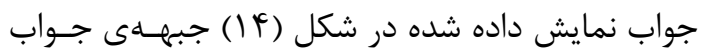

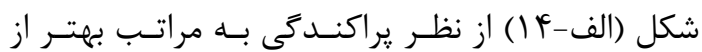

${ }^{1}$ Spacing Metric

${ }^{2}$ Diversity Metric 


$$
\Delta F=\left[\Delta f_{1}, \Delta f_{2}, \ldots, \Delta f_{m}\right] \quad \text { (1) }
$$

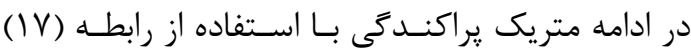
محاسبه مىشود. $D=\|\Delta F\|$

(IV) رابطه (s)

در رابطهى (IV) منظور از || (IV) همان نرم دوم بردار

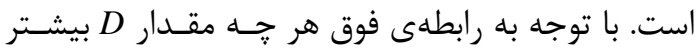

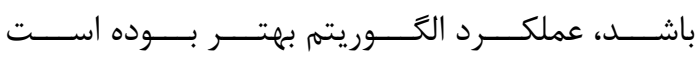

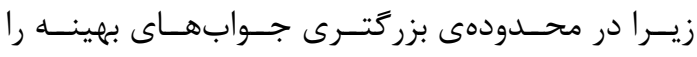

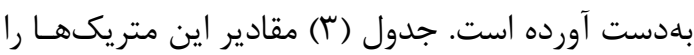
براى دو الكوريتم نشان مى دهد.

$$
\text { ه }
$$

اين متريك شاخصى براى بررسى بازمى جسـتجو شـــه

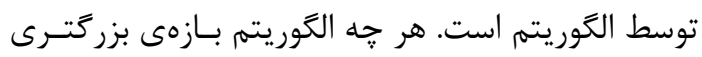

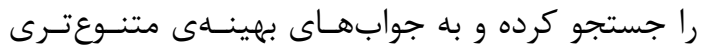

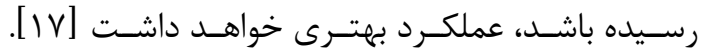

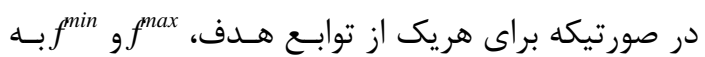

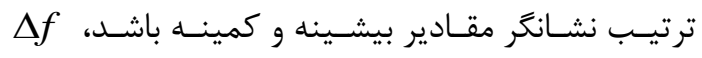

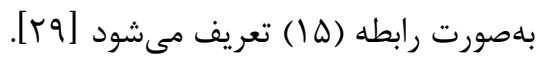

$$
\Delta f_{j}=f_{j}^{\max }-f_{j}^{\min }, j=1,2, \ldots, m \quad \text { رابطه (1) }
$$

كه در آن m تعداد توابع هـدف اسـت. همجنــــن بـردار

\begin{tabular}{|c|c|c|c|}
\hline زمان اجراى الخوريتم & متريك & متريك فاصله & الگوريتم \\
\hline$F \vee q \Delta F \wedge, \Delta V F T$ & ... .qrmq4 & $\cdot \Delta F \Delta \cdot V$ & NSGA-II \\
\hline$r m \Delta \cdot 91,919$ & 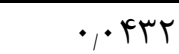 & - $\Delta S V M r$ & MOEA/D \\
\hline
\end{tabular}

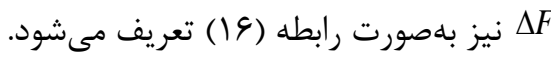

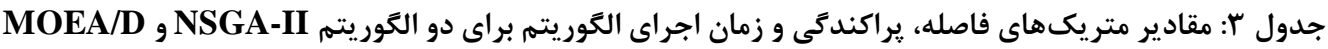

نيل به هدف مذكور در ابتدا المانهـاى كمسى و كيفى

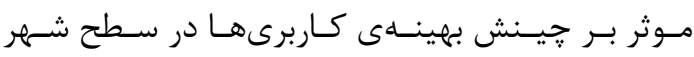

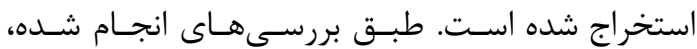

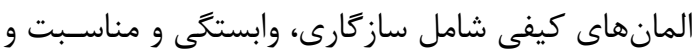

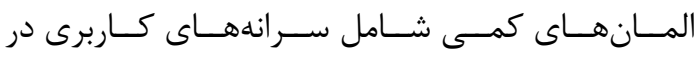

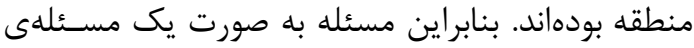

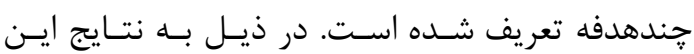
تحقيق برداخته شده است: با اينكه در تعريف تمامى اجزاى مدل سعى بر آن

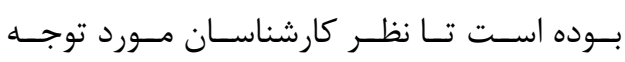

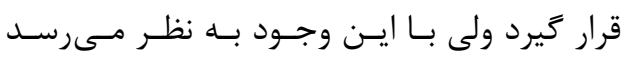

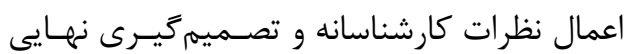
براى تغيير ساير كـاربرىهـا بـا توجـهـ بــه تغييـر

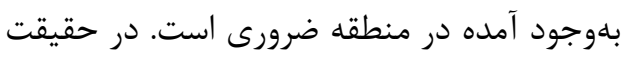

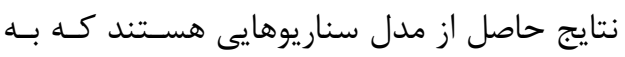

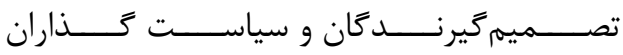
امكان تصميمخيرى دقيقتر و بهتر را مسىدهنــد و

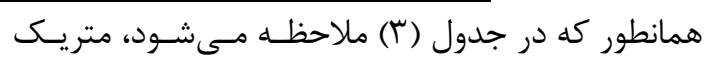

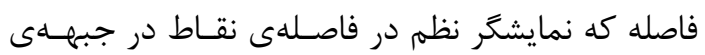

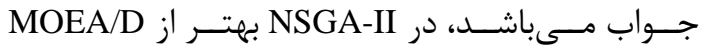
عمل كرده است. اين امر به دليل اسـتفادهى NSGA-II

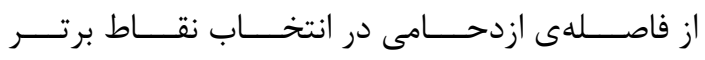
براى ايجاد نسلهاى بعدى مى باشد. اما در مورد متريك

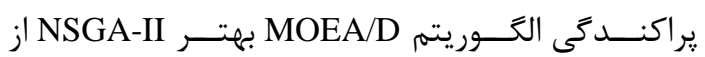

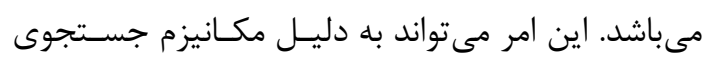
MOEA/D بر اساس بردارهاى وزن باشد. از نظـر زمـان

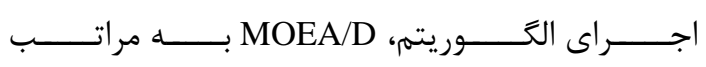

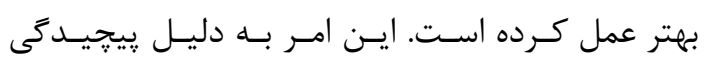
محاسباتى كمتر اين الكوريتم و عدم استفادهى مستقيم از مفهوم غلبكى در تعيين جوابها مىباشد. 9- نتيجه در اين تحقيق اثرات تغيير كاربرىهاى شهرى بر اساس

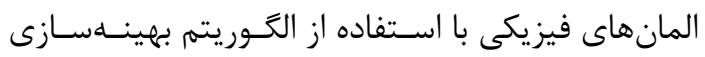

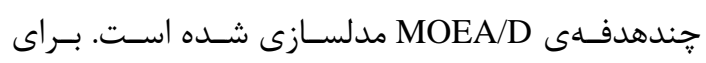


همجرنــين لازم اسـت بيشـــر بــهـ ديناميـك بــودن تغييرات كاربرىها در شهر توجه نمود.
مدل طراحى شده يك مدل حامى برنامـهريـزى و تصميم كيرى است.

نحوهى تعريف توابـع هـدف نقـش بسـيار مهـهم و كليـدى در نتـايج بـه دسـت آمـده از مــدل دارد.

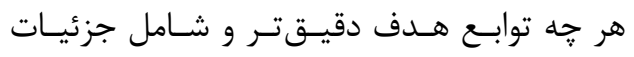

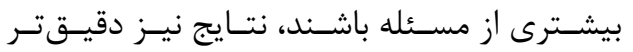

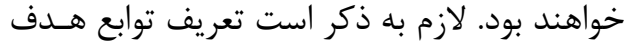

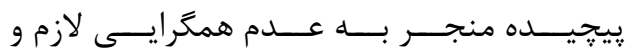
نتايج ضعيفتر خواهد بود. در حالت كلى همسـو كردن و تعريف توابع هدف در يـك مسـئله جـزءء

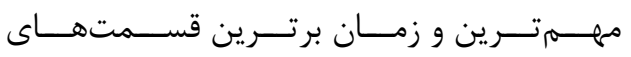

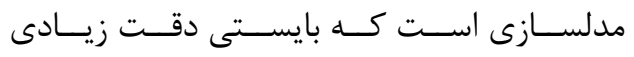
در اين مرحله داشت.

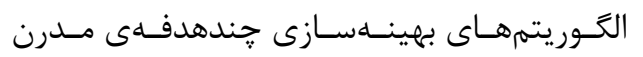

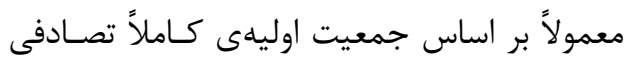

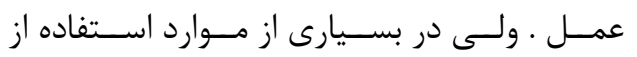

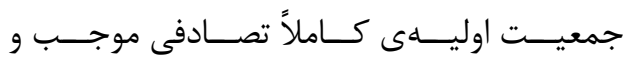
عدم دستيابى بـه نتـايج مناسـب مسىشـود. ايسن

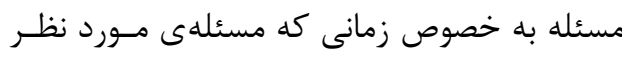

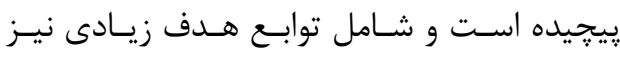
مىباشد تأثير بيشترى دارد. در اين موارد معمـولاًا

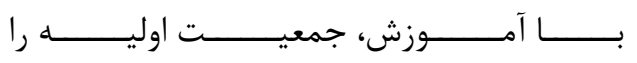
به سوى جمعيت اوليهى دلخواه هدايت مى كنـــد. به اين نوع جمعيت اوليه، 'PBI نيز كفته مي دئهود.

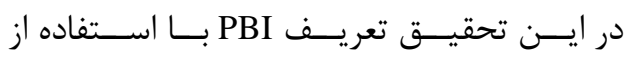

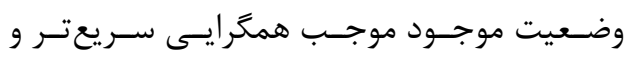
بهدست آمدن نتايج منطقى تر ترديت

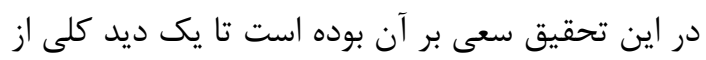

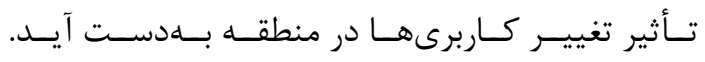

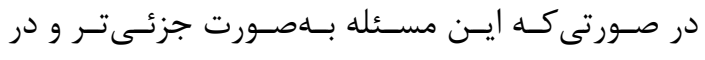

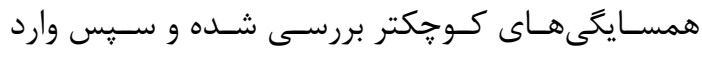

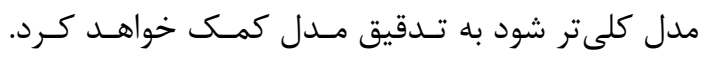

${ }^{1}$ Problem-Based Initial population 
[1] Hausen, M. A. "Dynamic Urban Design: A Handbook for Creating Sustainable Communities Worldwide" iUniverse, USA, 2012.

[2] Shiffa, M., Jianhua, H., Feng, L., \& Yan, Y. (2011). "Land-use spatial optimization based on PSO algorithm", Geo-spatial Information Science 14, 54:61.

[3] Liu, X., Ou, J., Li, X., \& Ai, B. "Combining system dynamics and hybrid particle swarm optimization for land use allocation”. Ecological Modelling, 257, 1124, 2013.

[4] YaoLin, L., \& JinJin, P. "A Fast Particle Swarm Optimization Algorithm for Land Use Allocation" Paper presented at the 12th International Conference on GeoComputation, Wuhan, China, 2013.

[5] Liu Y, Peng J, Jiao L, Liu Y, "PSOLA: A Heuristic Land-Use Allocation Model Using Patch- Level Operations and Knowledge-Informed Rules", PLoS ONE 11(6), 21-42, 2016.

[6] Cao, K., Batty, M., Huang, B., Liu, Y., Yu, L. \& Cheng, J., "Spatial multi-objective land use optimization: extensions to the non-dominated sorting genetic algorithmII", International Journal of Geographical Information Science, 1, 1-21, 2011.

[7] Zhang, Q., \& Li, H., "MOEA/D: A Multiobjective Evolutionary Algorithm Based on Decomposition". IEEE Transactions on Evolutionary Computation, 11(6), 712-731, 2007.

[8] Haque, A. and Asami, Y., Optimizing urban land use allocation for planners and real estate, developers, Computers, Environment and Urban Systems, Vol. 46, 57-69, 2014.

[9] Masoumi, Z., Mesgari, M.S., Hamrah, M., "Allocation of urban land uses by MultiObjective Particle Swarm Optimization algorithm" International Journal of Geographical Information Science, Vol.

\section{مراجع}

27(3), 1-25, 2013.

[10]Delaviz, Y., Shaygan, M., Karami, J., "Using NSGA-II in multi-objective urban land use optimization to decrease earthquake risk, Journal of Geomatic sciences and technology", Vol.5, Issue, 3. 247-264, 2014.

[11] Mashhoudi, S., "Fundamentals of urban dynamic plans", Urban Processing and Planning Co, Tehran, Iran, 2006.

[12] Pasione, M., "Urban Geography: A Global Perspective (3 rd ed.)". New York: Routledge, 2009.

[13] Seifadini, F., "Fundamental of urban planning, Aeezh publication", Tehran, Iran, 2008.

[14] Coello Coello, C. A., Lamount, G. B. and Veldhuizen, D. A. "Evolutionary algorithms for solving multi-objective problems". 2nd ed. New York: Springer, 2007.

[15] Branke, J., Deb, K., Miettinen, K., \& Slowiniski, R. "Multiobjective optimization: Interactive and Evolutionary Approache" Springer, 2008.

[16]Munier, N. “A Strategy for Using Multicriteria Analysis in Decision-Making: A Guide for Simple and Complex Environmental Projects (1st Edition ed.)". Valencia, Spain: Springer, 2011.

[17]Deb, K. "Multi-Objective Optimization Using Evolutionary Algorithm” New York, John Wiley and Sons, 2001.

[18] Talbi, E. "Metaheuristics: from desgin to implementation", New Jersey, John Wiley and Sons, 2009.

[19] Engelbrecht, A. P."Computational Intelligence: An Introduction” England, John Wiley \& Sons, 2007.

[20] Goldberg, D. E. \& Richardson, J. Year. "Genetic algorithms with sharing for multimodal function optimization". In: GREFENSTETTE, J. J., ed. 2nd 
international Conference on Gas: Genetic Algorithms and Their Applications, 1987 Cambridge. Massachusetts Institute of Technology, 41-49.

[21]Peng, W., Zhang, Q., \& Li, H. Comparison between MOEA/D and NSGA-II on the Multi-Objective Travelling Saleman Problem. In C. K. Goh, Y. S. Ong \& K. C. Tan (Eds.), Multi-Objective Memetic Algorithms (Vol. Studies in Computational Intelligence, pp. 309-324). Berlin: Springer, 2009.

[22] Ishibuchi, H., Sakane, Y., Tsukamoto, N., \& Nojima, Y. "Simultaneous use of different scalarizing functions in MOEA/D”. Paper presented at the Proceedings of the 12th annual conference on Genetic and evolutionary computation, 2010.

[23]Zhang, H., Zeng , Y., Jin , X., Shu , B., Zhou, Y., Yang, X., " Simulating multiobjective land use optimization allocation usingMulti-agent system-A case study in Changsha", China, Ecological Modelling, Vol. 320, 334-347, 2016

[24] Poormohammadi, M., "Urban land use planning”, Tehran university press, Tehran, Iran, 2008.
[25] Telei, M., Sharifi, A., Sliuzas, R. \& Mesgari, M. "Evaluating the compatibility of multi-functional and intensive urban land uses." International Journal of Applied Earth Observation and Geoinformation, 9, 375-391, 2006.

[26] Koomen, E., Rietveld, P. and Nijs, T. "Modelling land-use change for spatial planning support." Annals in Regional Science, 42, 1-10, 2008.

[27] Lagore, J., "Site Analysis, A Contextual Approach to Sustainable Land Planning and Site Design" Second ed. New Jersey: John Wiley \& Sons, 2008.

[28] Haupt, R. L. and Haupt, S. E." Practical Genetic Algorithms". 2nd ed. New Jersey: John Wiley \& Sons, 2004.

[29] Bajestani, M. A., et al. “A multi-objective scatter search for a dynamic cell formation problem.”, Operations Research, 36, 777794, 2009.

[30]Zitzler, E., Deb, K. and Thiele, L. “ Comparison of Multiobjective Evolutionary Algorithms: Empirical Results". Evolutionary Computation, 8(2), 173-195, 2002. 


\title{
Multi-Objective land use planning and modeling its change using Multi-Objective Evolutionary Algorithm based on Decomposition algorithm
}

\author{
Zohreh Masoumi $^{* 1}$, Mohammad Sadi Mesgari ${ }^{2}$ \\ 1- Assisstant professor in Department of Earth Sciences, Institute of Advanced Studies in Basic Sciences \\ 2- Associate professor in Departement of Geomatics in Khajeh Nasir Toosi University of Technology
}

\begin{abstract}
Considering rigidity in General and Detail urban plans, modeling the effects of changes mathematically would be worth in such plans. Investigating the effects of urban land use changes in the arrangement of other land uses and designing criteria such as consistency, dependency, suitability and per capita demand, always is a multi-objective and NP-hard problem. Due to the variety of urban land uses and their complex relationships with each other, many possible arrangements of land uses can be suggested. In this study, the main target is obtaining the effects of changes in one or more land uses in the arrangement of the other land uses considering three objective functions and one criteria simultaneously. These objective functions include consistency, dependency and suitability. Moreover, per capita demand assume as criteria in this research. To do so, MOEA/D algorithm is applied. Results demonstrate that the solutions are acceptable in the test of meta-heuristic algorithms. Furthermore, the results of the algorithm shows more optimized answer than current status. It is notable to say that the run time of this algorithm is considerably lower than other MOEAs like NSGA-II. Besides, the search space of MOEA/D is more expanded than NSGA-II.
\end{abstract}

Key words: Land use change modeling, Decision support, MOEA/D, GIS

Correspondence Address. : Department of earth sciences, Institute for advanced studies in basic sciences, No. 444, Prof. Yousef Sobouti Blvd. P. O. Box 45195-1159 Zanjan Iran

Tel: 024- 33153396

Email: z.masoumi@iasbs.ac.ir 